\title{
Thymosin Beta 4 Prevents Oxidative Stress by Targeting Antioxidant and Anti-Apoptotic Genes in Cardiac Fibroblasts
}

\author{
Sandeep Kumar, Sudhiranjan Gupta*
}

Division of Molecular Cardiology, Department of Molecular Medicine, College of Medicine, Texas A\&M Health Science Center, Scott \& White, Central Texas Veterans Health Care System, Temple, Texas, United States of America

\begin{abstract}
Rationale: Thymosin beta-4 (T $\beta 4)$ is a ubiquitous protein with diverse functions relating to cell proliferation and differentiation that promotes wound healing and modulates inflammatory responses. The effecter molecules targeted by $\mathrm{T} \beta 4$ for cardiac protection remains unknown. The purpose of this study is to determine the molecules targeted by T $\beta 4$ that mediate cardio-protection under oxidative stress.

Methods: Rat neonatal fibroblasts cells were exposed to hydrogen peroxide $\left(\mathrm{H}_{2} \mathrm{O}_{2}\right)$ in presence and absence of T及4 and expression of antioxidant, apoptotic and pro-fibrotic genes was evaluated by quantitative real-time PCR and western blotting. Reactive oxygen species (ROS) levels were estimated by DCF-DA using fluorescent microscopy and fluorimetry. Selected antioxidant and antiapoptotic genes were silenced by siRNA transfections in cardiac fibroblasts and the effect of $\mathrm{T} \beta 4$ on $\mathrm{H}_{2} \mathrm{O}_{2}$-induced profibrotic events was evaluated.

Results: Pre-treatment with T $\beta 4$ resulted in reduction of the intracellular ROS levels induced by $\mathrm{H}_{2} \mathrm{O}_{2}$ in the cardiac fibroblasts. This was associated with an increased expression of antioxidant enzymes $\mathrm{Cu} / \mathrm{Zn}$ superoxide dismutase (SOD) and catalase and reduction of $\mathrm{Bax} / \mathrm{BCl}_{2}$ ratio. $\mathrm{T} \beta 4$ treatment reduced the expression of pro-fibrotic genes [connective tissue growth factor (CTGF), collagen type-1 (Col-I) and collagen type-3 (Col-III)] in the cardiac fibroblasts. Silencing of Cu/Zn-SOD and catalase gene triggered apoptotic cell death in the cardiac fibroblasts, which was prevented by treatment with $T \beta 4$.

Conclusion: This is the first report that exhibits the targeted molecules modulated by T $\beta 4$ under oxidative stress utilizing the cardiac fibroblasts. T $\beta 4$ treatment prevented the profibrotic gene expression in the in vitro settings. Our findings indicate that $T \beta 4$ selectively targets and upregulates catalase, $\mathrm{Cu} / \mathrm{Zn}$-SOD and $\mathrm{Bcl}_{2}$, thereby, preventing $\mathrm{H}_{2} \mathrm{O}_{2}$-induced profibrotic changes in the myocardium. Further studies are warranted to elucidate the signaling pathways involved in the cardio-protection afforded by $\mathrm{T} \beta 4$.
\end{abstract}

Citation: Kumar S, Gupta S (2011) Thymosin Beta 4 Prevents Oxidative Stress by Targeting Antioxidant and Anti-Apoptotic Genes in Cardiac Fibroblasts. PLoS ONE 6(10): e26912. doi:10.1371/journal.pone.0026912

Editor: Hiranmoy Das, Ohio State University Medical Center, United States of America

Received June 27, 2011; Accepted October 6, 2011; Published October 25, 2011

Copyright: (C) 2011 Kumar, Gupta. This is an open-access article distributed under the terms of the Creative Commons Attribution License, which permits unrestricted use, distribution, and reproduction in any medium, provided the original author and source are credited.

Funding: This work is partly funded by Texas A\&M start-up funds and a Scientist Development Grant from The American Heart Association to S. Gupta. The funders had no role in study design, data collection and analysis, decision to publish, or preparation of the manuscript. No additional external funding was received for this study.

Competing Interests: The authors have declared that no competing interests exist.

*E-mail: sgupta@medicine.tamhsc.edu

\section{Introduction}

Reactive oxygen species (ROS) plays an important role in regulating a variety of cellular functions, including gene expression, cell growth and cell death and has been implicated as one of the major contributors of cardiac damage in various cardiac pathologies $[1,2,3]$. Increased ROS levels can cause damage to nucleic acids, lipids, and proteins and can directly damage the vascular cells, cardiac myocytes and cardiac fibroblasts [3,4]. Oxidative stress has been shown to be a precursor of cardiac apoptosis and has also been implicated in cardiac hypertrophy and fibrosis [5,6,7]. The declining protective enzymes and the reduced adaptive capacity to counter the oxidative stress cause activation of apoptotic death pathways [8]. Although, cells, tissues and organs utilize multiple layers of antioxidant defenses and damage removal, the heart is particularly more vulnerable to oxidative damage as it has a weak endogenous antioxidant defense system [9].
It has been suggested that an increased level of oxidative stress heart is primarily due to the functional uncoupling of the respiratory chain caused by inactivation of complex I in the mitochondria [10] or due to impaired antioxidant capacity, such as reduced activity of $\mathrm{Cu} / \mathrm{Zn}$ superoxide dismutase $(\mathrm{Cu} / \mathrm{Zn}-\mathrm{SOD})$ and catalase [6], or stimulation of enzymatic sources, including xanthine oxidase, cyclo-oxygenase, nitric oxide synthase, and nonphagocytic $\mathrm{NAD}(\mathrm{P}) \mathrm{H}$ oxidases [11]. Irrespective of the source of the stress stimuli involved, oxidative damage remains the main challenge and numerous efforts have been made to devise strategies to protect the heart against oxidative damage. Considerable attempts have been made in the recent decades to discover an "ideal" cardio-protective agent, which can abrogate the oxidative damage and maladaptive changes in the heart. In this pursuit, thymosin $\beta 4$ (T $\beta 4$ ) emerged as a powerful candidate.

$\mathrm{T} \beta 4$, a 43 amino acids, ubiquitous intracellular protein, bind to and sequester G- actin to modulate cell migration [12]. Recent 
studies implicated that T $\beta 4$ had multiple diverse physiological and pathological functions, such as wound healing, angiogenesis, preserved cardiac function after myocardial infarction which essentially depends on cell migration $[13,14,15]$. Essentially, T $\beta 4$ possesses cardiac tissue repair properties that cause epicardial cell migration, neovascularization and revascularization, and activation of cardiac progenitor cells in the heart $[16,17]$. Apart from the cardiac repair properties, it has been demonstrated that T $\beta 4$ protects human corneal epithelial cells and conjunctival cells from apoptosis after ethanol and hydrogen peroxide $\left(\mathrm{H}_{2} \mathrm{O}_{2}\right)$ injury $[18,19,20]$. A few reports exhibit the role of $\mathrm{T} \beta 4$ in the myocardial infarction settings where it promotes endothelial and myocardial cell survival, cardiac cell migration, activation of integrin linked kinase (ILK) and activation of Akt/Protein Kinase B that resulted in improved cardiac function and reduction in scarring [14,16,21]. In this context, we have shown that $\mathrm{T} \beta 4$ also plays a crucial role in cardiac protection by enhancing the levels of PINCH-1-ILK- $\alpha$ parvin components and promotes Akt activation while substantially suppressing NF- $\mathrm{KB}$ activation [22]. A recent report showed that $\mathrm{T} \beta 4$ upregulates anti-oxidative enzymes in human corneal cells against oxidative stress [23].

In this study, we used rat neonatal cardiac fibroblasts to study the effects of T $\beta 4$ under oxidative stress. The rationale for using cardiac fibroblasts in this study originates from the fact that apart from being the most abundant cell type in the mammalian heart $[24,25,26]$, the fibroblasts are intricately involved in myocardial development and cardiac protection under various stimuli $[27,28]$. Recently, it has been shown that cardiac fibroblasts also undergo apoptosis under myocardial damage which can further aggravate the myocardial injury [29] and this can occur independent of the myocyte death [30]. The action of $\mathrm{T} \beta 4$ on cardiac fibroblasts under oxidative stress and its effects are largely unknown. It was for this reason we utilized the cardiac fibroblasts in the in vitro model to study the cardioprotective effects of $\mathrm{T} \beta 4$ under oxidative stress.

Here, we showed the effects of T $\beta 4$ on ROS act ivy, antioxidant enzymes, anti-apoptotic and pro-fibrotic gene expression in preventing $\mathrm{H}_{2} \mathrm{O}_{2}$ induced oxidative stress in rat cardiac fibroblasts.

\section{Materials and Methods}

\section{Reagents}

3-(4,5-Dimethylthiazol-2-yl)-2,5-diphenyltetrazolium bromide (MTT), hydrogen peroxide $\left(\mathrm{H}_{2} \mathrm{O}_{2}\right)$, dimethyl sulfoxide (DMSO), 5-Bromo-2-DeoxyUridine, (BrdU) all were purchased from Sigma Life Science (St. Louis, MO, USA). Thymosin $\beta 4$ was purchased from ProSpec-Tany TechnoGene Ltd, (Rehovot, Israel). Dihydroethidium (DHE), 2',7'-dichlorodihydrofluorescein diacetate $\left(\mathrm{H}_{2} \mathrm{DCFH}-\mathrm{DA}\right)$, diaminofluorescein 2-diacetate (DAF-2DA), 3,3'-dihexyloxacarbocyanine iodide $\left(\mathrm{DiOC}_{6}\right)$, and chloromethylX-rosamine (MitoTracker Red), ProLong Gold anti-fade mounting media (anti-fade) were purchased from Molecular Probes (Eugene, OR, USA). Primary antibody for Mn-SOD was purchased from Upstate/Millipore (Billerica, MA, USA); Cu/ Zn-SOD from Assay Designs Inc., (Ann Arbor, MI, USA); catalase from Santa Cruz Biotechnology (Santa Cruz, CA, USA); collagen type I and collagen type III from Rockland Immunochemicals, (Gilbertsville, PA, USA); connective tissue growth factor (CTGF) from Abcam Inc. (Cambridge, MA, USA), Bax, Bcl 2 , caspase-3 and GAPDH were purchased from Cell Signaling Technology (Beverly, MA, USA). Protease inhibitor cocktail tablets were purchased from Roche GmbH, (Mann-heim, Germany). Dulbecco's Modified Eagle Medium (DMEM), non-essential amino acid cocktail, Antibiotic and anti-mycotic solution, insulin, transferrin and selenium (ITS), and fetal Bovine Serum (FBS) were all purchased from GIBCO, Invitrogen (Carlsbad, CA, USA).

\section{Cell culture and treatment}

Primary cultures of cardiac fibroblasts were prepared from ventricles of 1-3 day-old Wistar rats as described [31,32] and were plated at a field density of $2.5 \times 10^{4}$ cells per $\mathrm{cm}^{2}$ on coverslips, 6 well plates, $60 \mathrm{~mm}$ culture dishes, or $100 \mathrm{~mm}$ dishes as required with DMEM containing 10\% FBS. After $24 \mathrm{~h}$, cells were serum deprived overnight before stimulation. The dose of $100 \mu \mathrm{M} \mathrm{H}_{2} \mathrm{O}_{2}$ did not show any toxic effect and damage to the cells and was therefore used throughout the study. T $\beta 4$ was pretreated $2 \mathrm{~h}$ before the $\mathrm{H}_{2} \mathrm{O}_{2}$ challenge at a final concentration of $1 \mu \mathrm{g} / \mathrm{mL}$ which was based on the previous report [23]. The cardiac cell culture experiments were approved by Institutional Biosafety Committee (IBC) and IACUC, Texas A \& M University, Temple, TX.

\section{Standardization of $\mathrm{H}_{2} \mathrm{O}_{2}$ dose on cardiac fibroblasts}

To determine the optimal sub-lethal working concentration of $\mathrm{H}_{2} \mathrm{O}_{2}$ that is sufficient to induce oxidative stress but does not cause considerable cell death, the cell viability of cardiac fibroblasts under oxidative stress using a dose course of $\mathrm{H}_{2} \mathrm{O}_{2}(1$ to $250 \mu \mathrm{M})$ was evaluated by MTT assay as described [33]. The absorbance was measured at $570 \mathrm{~nm}$ using a microplate reader (Molecular Devices, SpectraMax 250). The effect of $\mathrm{T} \beta 4(1 \mu \mathrm{g} / \mathrm{mL})$ was assessed on the $\mathrm{H}_{2} \mathrm{O}_{2}$ challenge and the cytotoxicity curve was constructed and expressed as percentage cell viability compared to control. To rule out the possible direct interaction between MTT with $\mathrm{H}_{2} \mathrm{O}_{2}$ or $\mathrm{T} \beta 4$, the treatment media was aspirated before the addition of MTT solution.

\section{Quantification of intracellular ROS levels}

Cardiac fibroblasts after respective treatments were incubated with $50 \mu \mathrm{M} \mathrm{H}_{2}$ DCFH-DA at $37^{\circ} \mathrm{C}$ in the dark for $30 \mathrm{~min}$ as described [33]. To rule out the possible direct cleavage of nonfluorescent DCFH-DA to fluorescent DCF by the nonspecific intracellular esterases and extracellular esterases in the serum, the treatment media was completely removed before $\mathrm{H}_{2} \mathrm{DCFH}-\mathrm{DA}$ staining. Cells were then harvested, washed with phosphatebuffered saline (PBS), and re-suspended in $50 \mathrm{mM}$ HEPES buffer (5 mM HEPES, pH 7.4; $5 \mathrm{mM} \mathrm{KCl,} 140 \mathrm{mM} \mathrm{NaCl}, 2 \mathrm{mM}$ $\mathrm{CaCl}_{2}, 1 \mathrm{mM} \mathrm{MgCl}_{2}$ and $10 \mathrm{mM}$ glucose) before their fluorescence intensities were acquired by fluorimetry (SpectraMaxPro, USA).

\section{Confocal Microscopy}

For qualitative estimation of the levels of intracellular ROS, cells were seeded on coverslips in 6-well plates, treated and subsequently incubated with $50 \mu \mathrm{M} \mathrm{H}_{2} \mathrm{DCFH}-\mathrm{DA}$ at $37^{\circ} \mathrm{C}$ in the dark for $30 \mathrm{~min}$ as previously described [33]. Cells were then fixed with $2 \%$ paraformaldehyde, washed 3 times with PBS, and mounted using anti-fade on glass slides and observed under confocal laser scanning microscope (Fluoview FV1000) fitted with a $488 \mathrm{~nm}$ argon ion laser. Images were acquired using the F10ASW 1.5 Fluoview software (Olympus, Tokyo, Japan). Since, ROS induces generation of other ROS species and loss of mitochondrial membrane potential, we estimated the levels of other free radicals like superoxide and nitric oxide using fluorescent probes. For this, DHE, DAF-2DA and MitoTracker Red were used for estimation of superoxide $\left(\mathrm{O}_{2}{ }^{-}\right)$radicals, nitric oxide (NO) and mitochondrial membrane potential $(\Delta \psi \mathrm{m})$, respectively [33]. Image intensities from 15-20 fields of at least 
3-4 confocal images of the same treatment group were quantified using ImageJ version 1.34 (NIH, Bethesda, USA) as described previously by Elia et. al. [34]

\section{Western blot analysis}

For western blot analysis, cardiac fibroblasts were treated with or without $\mathrm{T} \beta 4$ for $2 \mathrm{~h}$ before treatment with $100 \mu \mathrm{M}$ of $\mathrm{H}_{2} \mathrm{O}_{2}$. Cells were washed with PBS and cytosolic protein extracts were prepared using 1X Cell Lysis buffer (Santa Cruz Biotechnology, CA, USA) supplemented with protease inhibitor cocktail. Protein concentrations were determined using the Bradford assay (BioRad) as per manufacturer's protocol. Aliquots of protein lysates (40 $\mu \mathrm{g} /$ lane) were separated on sodium dodecyl sulfate- $10 \%$ polyacrylamide gels and western blotting was performed as described previously [31]. The primary antibodies used in this study include Mn-SOD, $\mathrm{Cu} / \mathrm{Zn}-\mathrm{SOD}$, catalase, $\mathrm{Bcl}_{2}$, Bax, Caspase-3, Col-I, Col-III, CTGF and GAPDH. The detection was performed using chemiluminescence assay (Cell Signaling Technology, Beverly, MA). Membranes were exposed to x-ray film to observe the bands (Kodak, Rochester, NY). The quantification of each western blot was measured by densitometry as described previously [31]. The changes observed as a result of $\mathrm{H}_{2} \mathrm{O}_{2}$ stimulation were expressed as fold change while the changes observed as a result of $\mathrm{T} \beta 4$ treatment were depicted as percent increase or decrease unless otherwise noted.

\section{RNA isolation and quantitative real-time PCR (q-RT-PCR) analyses}

Total RNAs from the cardiac fibroblasts were extracted using RNEasy kit (Qiagen, Stanford, Valencia, CA) as per the manufacturer's instructions. For real-time RT-PCR, $200 \mathrm{ng}$ to $1 \mu \mathrm{g}$ of total RNAs was reverse transcribed to cDNA using high capacity cDNA synthesis kit (Applied Bio systems, Foster City, CA, USA) following the manufacturer's protocols. Quantitative PCR was then carried out in a MX-3005 real-time PCR equipment (Stratagene, Cedar Creek, USA), using $2 \mu \mathrm{l}$ (20 ng) of cDNA template, $1 \mathrm{nmol}$ of primers, and $12.5 \mu \mathrm{l}$ of iQ SYBR green supermix (Bio-Rad, Hercules, CA) in a total volume of $25 \mu \mathrm{l}$ reaction. The primers used for the quantitative PCR are shown in Table 1 . The cDNA were amplified with initial denaturation at $95^{\circ} \mathrm{C}$ for $10 \mathrm{~min}$, followed PCR by 40 cycles of: $95^{\circ} \mathrm{C} 30 \mathrm{~s}, 60^{\circ} \mathrm{C}$ $30 \mathrm{~s}, 72^{\circ} \mathrm{C} 40 \mathrm{~s}$ and finally 1 cycle of melting curve following cooling at $40^{\circ} \mathrm{C}$ for $10 \mathrm{~s}$. To confirm amplification specificity the PCR products from each primer pair were subjected to a melting curve analysis. Analysis of relative gene expression was done by evaluating q-RT-PCR data by $2^{(-\Delta \Delta \mathrm{Ct})}$ method as described by others $[35,36]$. Each experiment was repeated at least three times and GAPDH or $18 \mathrm{~S}$ was used as housekeeping gene for internal control. The changes observed as a result of $\mathrm{H}_{2} \mathrm{O}_{2}$ stimulation were expressed as fold change while the changes observed as a result of T $\beta 4$ treatment were depicted as percent increase or decrease unless otherwise noted.

\section{RNA interference and siRNA transfection}

Silencing of $\mathrm{Cu} / \mathrm{Zn}-\mathrm{SOD}$, catalase and $\mathrm{Bcl}_{2}$ proteins was achieved by using small interfering RNA (si-RNA) transfections. Pre-designed double-stranded si-RNA against $\mathrm{Cu} / \mathrm{Zn}-\mathrm{SOD}$ (SASI_Rn01_00112871), catalase (SASI_Rn01_00053417) and $\mathrm{Bcl}_{2}$ (SASI_Rn01_00062026) were purchased from Sigma Life Science (Saint Louis, MO, USA). As a negative control, non-targeting control si-RNA (scrambled si-RNA), verified to have no significant effect on most essential mammalian genes, was obtained from Sigma. Rat neonatal fibroblasts were seeded into 6-well plates with
Table 1. List of quantitative real-time PCR used in the study.

\begin{tabular}{lll}
\hline Gene & Forward Primer & Reverse Primer \\
\hline CTGF & ACTATGATGCGAGCCAACTGC & TGTCCGGATGCACTTTTGC \\
Collagen 1 & TGGCCTTGGAGGAACTTTG & CTTGAAACCTTGTGGACCAG \\
Fibronectin & TGCAGTGACCAACATTGATCGC & AAAAGCTCCCGGATTCCATCC \\
Mn-SOD & TGGACAAACCTGAGCCCTAA & GACCCAAAGTCACGCTTGATA \\
Cu/Zn-SOD & TGGGAGAGCTTGTAGGTG & CACCAGTAGCAGGTTGCAGA \\
Catalase & ATCAGGGATGCCATGTTGT & GGGTCCTTCAGGTGAGTTTG \\
BCl 2 & GTACCTGAACCGGCATCTG & GGGGCCATATAGTTCCACAA \\
BAX & CGAGCTGATCAGAACCATCA & GGGGTCCCGAAGTAGGAA \\
GAPDH & CCAGGTGGTCCTCTGACTTC & GTGGTCGTTGAGGGCAATG \\
18S & TGTTCACCATGAGGCTGAGATC & TGGTTGCCTGGGAAAATCC \\
\hline doi:10.1371/journal.pone.0026912.t001 &
\end{tabular}

$3 \mathrm{~mL}$ of complete DMEM. After $24 \mathrm{~h}$, the medium was replaced with $2 \mathrm{~mL}$ of Opti-MEM (Life Technologies). Cells were then transfected with $200 \mathrm{pmol}$ of the siRNAs for catalase, $\mathrm{Cu} / \mathrm{Zn}$ $\mathrm{SOD}, \mathrm{Bcl}_{2}$ or negative control siRNA using N-TER ${ }^{\mathrm{TM}}$ nanoparticle siRNA transfection system (Sigma) as per the manufacturer's protocol. After $24 \mathrm{~h}$ of transfection, cells were treated and harvested to determine the transfection efficiency and effect of $\mathrm{T} \beta 4$ in presence and absence of $\mathrm{H}_{2} \mathrm{O}_{2}$ treatment. Quantification of caspase- 3 gene expression by q-RT- PCR was done to study the extent of pro-apoptotic gene expression.

\section{TUNEL staining}

Quantification of TUNEL staining was done to study the extent of apoptotic cell death on transfected fibroblasts by in situ cell death detection kit (Roche Applied Science, Indianapolis, IN). Briefly, $2 \times 10^{5}$ fibroblasts were seed on the coverslips in the 6 -well plates, followed by siRNA transfections and treatment. The TUNEL staining was done using deoxyneucleotidyl transferase (TdT) and FITC-labeled 2'-deoxyuridine $5{ }^{\prime}$-triphosphate (dUTP) as per manufacturer's instructions. The Analysis was done using 3-5 images from hi-power field (40X objective) and the TUNEL index $(\%)$ was calculated as the number of TUNEL-positive cells divided by the total number of DAPI-stained nuclei.

\section{Statistical analyses}

All experiments were performed at least three times for each determination. Data are expressed as means \pm Standard Error (SE) and were analyzed using student t-test or one-way analysis of variance (ANOVA) and secondary analysis for significance with Tukey-Kramer post tests using Prism 5.0 Graph Pad software (Graph Pad, San Diego, CA, USA). A p value less than 0.05 was considered statistically significant.

\section{Results}

\section{Pretreatment with T $\beta 4$ improves cardiac fibroblasts} survival

The viability of cardiac fibroblasts cells was assessed after treating the cells with various concentrations of $\mathrm{H}_{2} \mathrm{O}_{2}$ for $24 \mathrm{~h}$ by MTT assay. We observed that the $50 \%$ lethal dose $\left(\mathrm{LD}_{50}\right)$ of $\mathrm{H}_{2} \mathrm{O}_{2}$ on these cells was between 150 and $250 \mu \mathrm{M}$ (Figure 1A). Pretreatment with $\mathrm{T} \beta 4(1 \mu \mathrm{g} / \mathrm{mL})$ resulted in an improved cell survival count $(19.2 \% ; \mathrm{p}<0.05)$ compared to the untreated group. This beneficial effect of pretreatment was observed until $100 \mathrm{uM}$ 


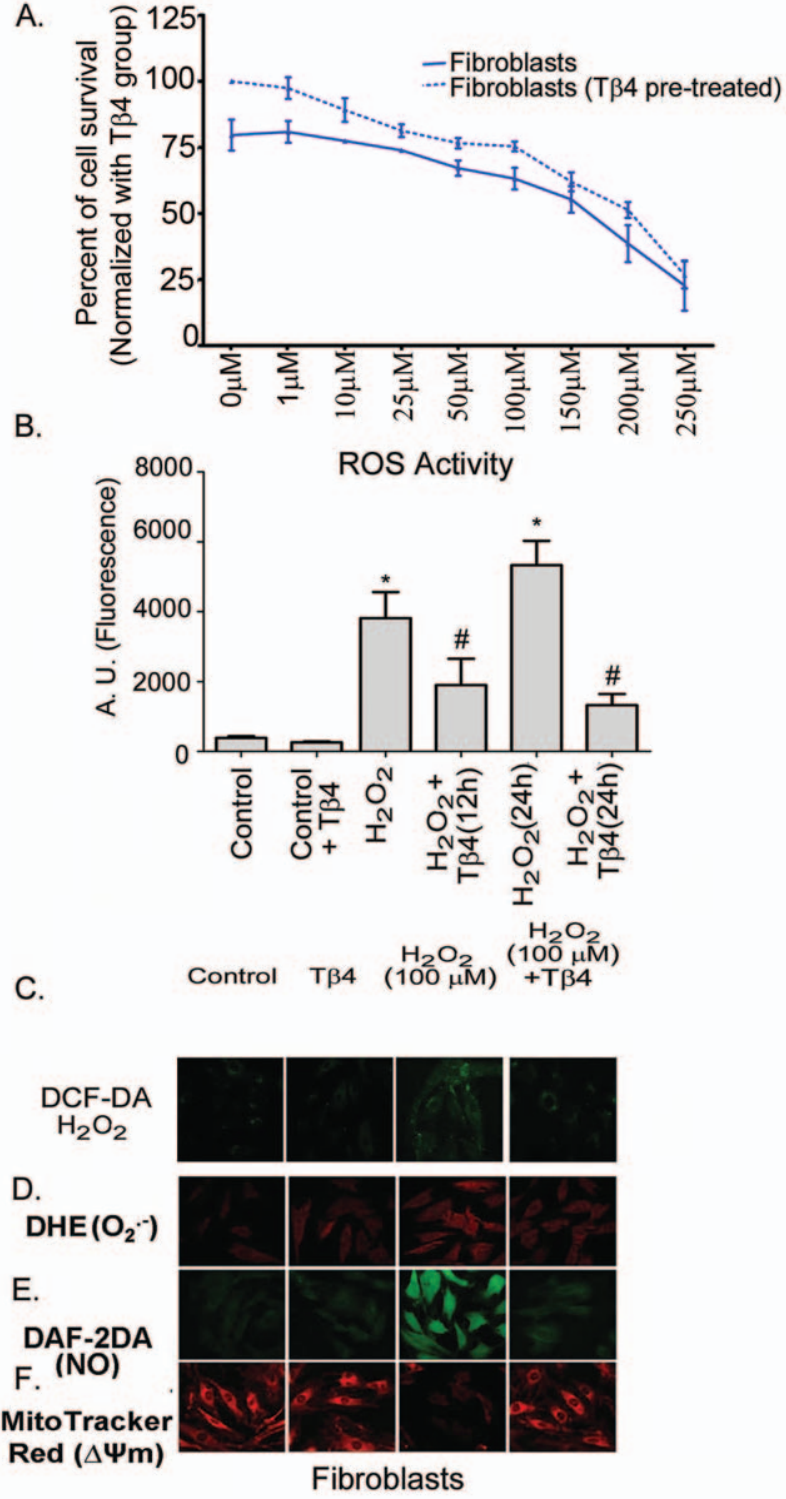

Figure 1. Effect of Tß3 on cell viability in $\mathrm{H}_{2} \mathrm{O}_{2}$ treated fibroblasts. (A) The MTT assay was performed with increasing $\mathrm{H}_{2} \mathrm{O}_{2}$ concentration (1 to $250 \mu \mathrm{M}$ ) in presence (dotted lines) and absence (solid lines) of T $\beta 4(1 \mu \mathrm{g} / \mathrm{mL})$. Data represent means \pm SEM of 3 individual experiments. (B) Representative confocal laser scanning microscopy images of cardiac fibroblasts stained with DCF-DA showing the effect of T $\beta 4$ on intracellular ROS upon treatment with $\mathrm{H}_{2} \mathrm{O}_{2}$. (C). Effect of T $\beta 4$ on generation of ROS in fibroblasts treated with $\mathrm{H}_{2} \mathrm{O}_{2}$ by fluorimetry. The graph represents the percentage of fluorescence positive fibroblasts upon staining with DCF-DA. Data represent the mean \pm SE of at least three separate experiments. ${ }^{*}$ means $p<0.05$ compared to the controls and \# represents $p<0.05$ compared to the respective $\mathrm{H}_{2} \mathrm{O}_{2}$ treated group (D) Representative confocal laser scanning microscopy images of cells stained with DHE Red showing the effect of T $\beta 4$ on generation of superoxide radicals upon treatment with $\mathrm{H}_{2} \mathrm{O}_{2}$ in fibroblast. (E). Representative confocal laser scanning microscopy images of cells stained with DAF-2DA showing the effect of $T \beta 4$ on generation of nitric oxide upon treatment with $\mathrm{H}_{2} \mathrm{O}_{2}$ in fibroblast. (F). Representative confocal laser scanning microscopy images of cells stained with Mitotracker Red showing the effect of $\mathrm{T} \beta 4$ on loss of mitochondrial membrane potential upon treatment with $\mathrm{H}_{2} \mathrm{O}_{2}$ in fibroblast.

doi:10.1371/journal.pone.0026912.g001
$\mathrm{H}_{2} \mathrm{O}_{2}$ concentration after which the pretreatment effect of T $\beta 4$ was compromised. This indicated a potential role of $\mathrm{T} \beta 4$ in protecting the cardiac fibroblasts against cell death due to generation of ROS. The optimal concentration of $\mathrm{H}_{2} \mathrm{O}_{2}$ was determined from MTT experiment and thus standardized dose of $100 \mu \mathrm{M} \mathrm{H}_{2} \mathrm{O}_{2}$ which was used throughout the study.

\section{$T \beta 4$ protects cardiac fibroblasts against $\mathrm{H}_{2} \mathrm{O}_{2}$ induced oxidative stress}

Oxidative stress leads to detrimental changes in the cell signaling process. To determine whether $\mathrm{T} \beta 4$ has any effect on ROS activity under oxidative stress, intracellular ROS levels in the cardiac fibroblast were estimated after $\mathrm{H}_{2} \mathrm{O}_{2}$ treatment by confocal microscopy and fluorimetry. Cardiac fibroblasts treated with $\mathrm{H}_{2} \mathrm{O}_{2}$ showed enhancement of fluorescence intensity of DCF-DA by 9.9 -fold at $12 \mathrm{~h}(\mathrm{p}<0.01)$ and 13.8fold at $24 \mathrm{~h}(\mathrm{p}<0.01)$, respectively, compared to the untreated controls (Figure 1B). Pretreatment with T $\beta 4$ showed a $50.2 \%$ decrease at $12 \mathrm{~h}(\mathrm{p}<0.05)$ and $75.1 \%$ at $24 \mathrm{~h} \quad(\mathrm{p}<0.05)$, respectively, compared to $\mathrm{H}_{2} \mathrm{O}_{2}$ treated cardiac fibroblasts. T $\beta 4$ treatment reduced the DCF-DA fluorescence by $32.2 \%$ $(\mathrm{p}<0.01)$ in the unstimulated cardiac fibroblast indicating that T $\beta 4$ treatment was effective in preventing oxidative stress in cardiac fibroblasts. The confocal microscopy images matched with the quantitative fluorimetry results (Figure 1C). Our data indicated that $\mathrm{T} \beta 4$ abrogated the ROS activity significantly in cardiac fibroblasts.

$T \beta 4$ reduces the formation of superoxide radicals and nitric oxide

Oxidative stress generated superoxide and nitric oxide radicals. These can lead to production of more noxious free radicals, like peroxynitrite $\left(\mathrm{ONOO}^{-}\right)$. To evaluate the effect of $\mathrm{T} \beta 4$ in superoxide and nitric oxide radical generation in cardiac fibroblasts, we estimated the levels of those free radical generations from $\mathrm{H}_{2} \mathrm{O}_{2}$ treatment by using confocal microscopy. The confocal microscopy data showed that $\mathrm{H}_{2} \mathrm{O}_{2}$ treated cells enhanced the fluorescence intensity of DHE and DAF-2DA, an indicator of increased $\mathrm{O}_{2}^{--}$and $\mathrm{NO}$ radicals, compared to the controls (Figure 1D and E). The enhanced fluorescence intensity of DHE and $\mathrm{DAF}-2 \mathrm{~A}$ was prevented by $\mathrm{T} \beta 4$ pretreatment, compared to the $\mathrm{H}_{2} \mathrm{O}_{2}$ treated cells (Figure $1 \mathrm{D}$ and $\mathrm{E}$ ). The quantifications of image intensities were tabulated in Table 2. Together, our data suggest that $\mathrm{T} \beta 4$ attenuated $\mathrm{H}_{2} \mathrm{O}_{2}$ induced superoxide and nitric oxide radical generation in cardiac fibroblasts.

\section{$T \beta 4$ treatment prevents the loss of mitochondrial membrane potential $(\Delta \psi \mathrm{m})$}

Oxidative stress impacts the mitochondrial function leading to disruption of electron transport and loss of mitochondrial transmembrane potential. We evaluated the effect of T $\beta 4$ on the mitochondrial membrane potential in the cardiac fibroblast under $\mathrm{H}_{2} \mathrm{O}_{2}$ induced oxidative stress using MitoTracker ${ }^{\circledR}$ Red by confocal microscopy. Our data showed that there was loss of $\Delta \psi \mathrm{m}$ as indicated by a decrease in the fluorescence intensity of MitoTracker ${ }^{\circledR}$ Red in $\mathrm{H}_{2} \mathrm{O}_{2}$-treated cells. This decrease in the fluorescence intensity was prevented by the pretreatment with $\mathrm{T} \beta 4$ (Figure $1 \mathrm{~F}$ ) suggesting that $\mathrm{T} \beta 4$ protected mitochondrial function by preventing the loss of $\Delta \psi \mathrm{m}$ in the cardiac fibroblast. The quantifications of image intensities were tabulated in Table 2. Our data suggest that $\mathrm{T} \beta 4$ treatment significantly reduced mitochondrial potential in $\mathrm{H}_{2} \mathrm{O}_{2}$ treated cardiac fibroblasts. 
Table 2. Image intensities (Arbitrary Units) showing the fluorescence intensities in cardiac fibroblasts upon staining with DCF-DA, DHE, DAF-2DA and MitoTracker Red.

\begin{tabular}{llllll}
\hline S. No. & Staining & Control & $\mathbf{T} \mathbf{3 4}$ & $\mathbf{H}_{\mathbf{2}} \mathbf{O}_{\mathbf{2}}$ & $\mathbf{H}_{\mathbf{2}} \mathbf{O}_{\mathbf{2}}+\mathbf{T} \mathbf{\beta 4}$ \\
\hline 1 & DCF-DA $\left(\mathrm{H}_{2} \mathrm{O}_{2}\right)$ & $259 \pm 48$ & $96 \pm 19^{*}$ & $614 \pm 26^{*}$ & $183 \pm 41^{\#}$ \\
2 & DHE $\left(\mathrm{O}_{2}^{-}\right.$radicals) & $428 \pm 52$ & $461 \pm 81$ & $892 \pm 62^{*}$ & $659 \pm 35^{\#}$ \\
3 & DAF-2DA (NO) & $305 \pm 43$ & $274 \pm 43$ & $948 \pm 47^{*}$ & $308 \pm 41^{\#}$ \\
4 & MitoTracker Red $(\Delta \psi \mathrm{m})$ & $644 \pm 58$ & $657 \pm 73$ & $253 \pm 45^{*}$ & $618 \pm 38^{\#}$ \\
\hline $\begin{array}{l}\text { Data acquired from at least } 15 \text { fields taken from 3-4 different confocal images } \\
\text { of the same treatment group and were quantified by using ImageJ Software. } \\
{ }^{*} \text { denotes } \mathrm{p}<0.05 \text { compared to controls while. } \\
\# \text { denotes } \mathrm{p}<0.05, \text { compared to the } \mathrm{H}_{2} \mathrm{O}_{2} \text {-treated group. } \\
\text { doi:10.1371/journal.pone.0026912.t002 }\end{array}$ & & & \\
\end{tabular}

$T \beta 4$ selectively upregulates the expression of antioxidant genes in cardiac fibroblasts under oxidative stress

We examined the effect of T $\beta 4$ on mRNA expression of antioxidant genes like Mn-SOD, Gu/Zn-SOD and catalase in cardiac fibroblasts under oxidative stress by q-RT- PCR. Our data showed that there was an increase in the expression of MnSOD in the $\mathrm{H}_{2} \mathrm{O}_{2}$-treated cells by 2.7 -fold and 1.3-fold increase at 12 and $24 \mathrm{~h}$, respectively, compared to the untreated cells. $\mathrm{T} \beta 4$ treatment did not alter the mRNA expression of Mn-SOD at these time points, compared to the $\mathrm{H}_{2} \mathrm{O}_{2}$-treated groups (Figure 2A). $\mathrm{H}_{2} \mathrm{O}_{2}$ treatment reduced the mRNA expression of $\mathrm{Cu} / \mathrm{Zn}-\mathrm{SOD}$ by $95 \%$ at $12 \mathrm{~h}(\mathrm{p}<0.05)$ and $98 \%$ at $24 \mathrm{~h}$ $(p<0.05)$, respectively, compared to the untreated cells. Treatment with $\mathrm{T} \beta 4$ resulted in an increase of expression of $\mathrm{Cu} / \mathrm{Zn}$ SOD. T $\beta 4$ pretreatment restored the $\mathrm{Cu} / \mathrm{Zn}-\mathrm{SOD}$ mRNA expression back to normal levels both at $12 \mathrm{~h}$ and $24 \mathrm{~h}$, respectively, compared to the $\mathrm{H}_{2} \mathrm{O}_{2}$ treated cells (Figure 2B). In unstimulated cell, the mRNA expression of catalase was upregulated by 1.3 -fold after T $\beta 4$ treatment. $\mathrm{H} 2 \mathrm{O} 2$ treatment reduces the catalase mRNA expression by $50 \%(\mathrm{p}<0.05)$ and $89 \%(\mathrm{p}<0.05)$ at 12 and $24 \mathrm{~h}$ treatment, respectively, compared to the control. Pretreatment with T $\beta 4$ upregulated the catalase mRNA expression by 1.5 -fold $(\mathrm{p}<0.05)$, and 6.4 -fold $(\mathrm{p}<0.05)$ at $12 \mathrm{~h}$ and $24 \mathrm{~h}$, respectively, compared to the $\mathrm{H}_{2} \mathrm{O}_{2}$ treated cells (Figure 2C).

To examine the status of the above antioxidant genes at the translational levels, western blots were performed. Our data showed that the expression level of Mn-SOD was relatively unchanged at protein level at $12 \mathrm{~h}$ and $24 \mathrm{~h}$, respectively. Treatment with T $\beta 4$ did not alter the expression of Mn-SOD (Figure 2D). Compared to the untreated cells, H2O2 treatment showed a decline of $\mathrm{Cu} / \mathrm{Zn}-\mathrm{SOD}$ protein expression by $23 \%$ $(\mathrm{p}<0.05)$ and $24.6 \%(\mathrm{p}<0.05)$ at $12 \mathrm{~h}$ and $24 \mathrm{~h}$, respectively, compared to the controls. Cells pretreated with $\mathrm{T} \beta 4$ showed a 2.0 -fold $(\mathrm{p}<0.05)$ and 1.4 -fold $(\mathrm{p}<0.05)$ increased in the expression of $\mathrm{Cu} / \mathrm{Zn}-\mathrm{SOD}$ at $12 \mathrm{~h}$ and $24 \mathrm{~h}$ treatment, respectively, compared to the $\mathrm{H}_{2} \mathrm{O}_{2}$ treated cells (Figure 2D). The expression of catalase declined by $25 \%(\mathrm{p}<0.05)$ at $12 \mathrm{~h}$ and $15 \%(\mathrm{p}<0.05)$ at $24 \mathrm{~h}$, respectively, with $\mathrm{H}_{2} \mathrm{O}_{2}$ treatment compared to untreated cells. T $\beta 4$ pretreatment increased catalase expression by 1.3 -fold $(\mathrm{p}<0.05)$ and 1.4 -fold $(\mathrm{p}<0.05)$ increase at $12 \mathrm{~h}$ and $24 \mathrm{~h}$, respectively, compared to the $\mathrm{H}_{2} \mathrm{O}_{2}$ treated cells (Figure 2D). The normalized quantification for Mn-SOD, Cu/ $\mathrm{Zn}-\mathrm{SOD}$ and catalase expression by densitometry is shown in the Figure 2E.
T $\beta 4$ promotes cell survival by increasing the expression of anti-apoptotic genes and reducing the expression proapoptotic genes in cardiac fibroblasts under oxidative stress

To examine the effect of $\mathrm{T} \beta 4$ on cardiac death and survival, we determine the expression of caspase-3, Bax (pro-apoptotic) and $\mathrm{Bcl}_{2}$ (anti-apoptotic) in presence and absence of $\mathrm{H}_{2} \mathrm{O}_{2}$ by qRT-PCR. $\mathrm{H}_{2} \mathrm{O}_{2}$ treatment upregulated the caspase- 3 expression by 3.0 -fold $(\mathrm{p}<0.05)$ and 5.0-fold $(\mathrm{p}<0.05)$ at $12 \mathrm{~h}$ and $24 \mathrm{~h}$ treatment, respectively, compared to the untreated cells. T $\beta 4$ pretreatment resulted in 29\% $(\mathrm{p}<0.05)$ and $19 \%(\mathrm{p}<0.05)$ decrease in the mRNA expression of caspase- 3 at $12 \mathrm{~h}$ and $24 \mathrm{~h}$ treatment, compared to $\mathrm{H}_{2} \mathrm{O}_{2}$ treated cells (Figure $3 \mathrm{~A}$ ). $\mathrm{H}_{2} \mathrm{O}_{2}$ treatment increased mRNA expression of Bax by 1.6-fold $(\mathrm{p}<0.05)$ and 2.1 -fold $(\mathrm{p}<0.05)$ at $12 \mathrm{~h}$ and $24 \mathrm{~h}$, respectively, compared to untreated cells. The mRNA expression of Bax was reduced by $31 \%(\mathrm{p}<0.05)$ and $26 \%(\mathrm{p}<0.05)$ at $12 \mathrm{~h}$ and $24 \mathrm{~h}$, respectively with pretreatment $\mathrm{T} \beta 4$ treatment (Figure 3B). The mRNA expression of $\mathrm{Bcl}_{2}$ concomitantly decreased by $11 \%(\mathrm{p}<0.05)$ and $23 \%(\mathrm{p}<0.05)$ at $12 \mathrm{~h}$ and $24 \mathrm{~h}$, respectively in $\mathrm{H}_{2} \mathrm{O}_{2}$ treatment. The mRNA levels of $\mathrm{Bcl}_{2}$ was increased by pretreatment with $\mathrm{T} \beta 4$ by $20 \%(\mathrm{p}<0.05)$ and $14 \%(\mathrm{p}<0.05)$ at $12 \mathrm{~h}$ and $24 \mathrm{~h}$, respectively, compared to $\mathrm{H}_{2} \mathrm{O}_{2}$-treated cells (Figure $3 \mathrm{C}$ ).

At translational level, $\mathrm{H}_{2} \mathrm{O}_{2}$ treatment resulted in a 2.8-fold $(\mathrm{p}<0.05)$ and 2.6-fold $(\mathrm{p}<0.05)$ increase in the expression of caspase-3 protein at $12 \mathrm{~h}$ and $24 \mathrm{~h}$ period, respectively, compared to the untreated cells. T $\beta 4$ pretreatment showed 39\% $(\mathrm{p}<0.05)$ and $9 \%$ $(\mathrm{p}=\mathrm{ns})$ decrease in the caspase- 3 expression at the above time point, compared to $\mathrm{H}_{2} \mathrm{O}_{2}$-treated cells. (Figure $3 \mathrm{D}$ ). GAPDH was used as internal loading control. The normalized quantification of caspase-3 by western blotting is shown in the Figure $3 \mathrm{E} . \mathrm{H}_{2} \mathrm{O}_{2}$ treatment showed an increase in the $\mathrm{Bax} / \mathrm{Bcl}_{2}$ ratio by 1.8 -fold $(\mathrm{p}<0.05)$ and 2.3 -fold $(\mathrm{p}<0.05)$ at $12 \mathrm{~h}$ and $24 \mathrm{~h}$, respectively, compared to the controls. T $\beta 4$ treatment significantly prevented this increase in the $\mathrm{Bax} / \mathrm{Bcl}_{2}$ ratio by $31 \%(\mathrm{p}<0.05)$ and $43 \%(\mathrm{p}<0.05)$ at $12 \mathrm{~h}$ and $24 \mathrm{~h}$, respectively, compared to $\mathrm{H}_{2} \mathrm{O}_{2}$-treated cells (Figure $3 \mathrm{E}$ ).

\section{$T \beta 4$ reduced the expression of pro-fibrotic genes in cardiac fibroblast under oxidative stress}

We next determine the pro-fibrotic gene expression under oxidative stress condition. Our data showed that $\mathrm{H}_{2} \mathrm{O}_{2}$ treatment increased the mRNA expression of CTGF by 2.3-fold $(\mathrm{p}<0.05)$ and 2.3 -fold $(\mathrm{p}<0.05)$ at $12 \mathrm{~h}$ and $24 \mathrm{~h}$, respectively, compared to the controls. T $\beta 4$ treatment showed reduction in the mRNA expression of CTGF by $17 \%(\mathrm{p}<0.05)$ and $38 \%(\mathrm{p}<0.05)$ at $12 \mathrm{~h}$ and $24 \mathrm{~h}$, respectively (Figure $4 \mathrm{~A}$ ). The mRNA expression of collagen-1 was increased by 4.0 -fold $(\mathrm{p}<0.05)$ and 5.7 -fold $(\mathrm{p}<0.05)$ at $12 \mathrm{~h}$ and $24 \mathrm{~h}$, respectively, in $\mathrm{H}_{2} \mathrm{O}_{2}$-treated cells compared to the controls. T $\beta 4$ pretreatment decreased collagen-I by $46 \%(\mathrm{p}<0.05)$ and $42 \%$ $(\mathrm{p}<0.05)$ at $12 \mathrm{~h}$ and $24 \mathrm{~h}$, respectively, compared to the $\mathrm{H}_{2} \mathrm{O}_{2^{-}}$ treated cells (Figure $4 \mathrm{~B}$ ). The mRNA expression of fibronectin was increased by 2.1 -fold $(\mathrm{p}<0.05)$ and 3.3-fold $(\mathrm{p}<0.05)$ at $12 \mathrm{~h}$ and $24 \mathrm{~h}$, respectively, in the $\mathrm{H}_{2} \mathrm{O}_{2}$-treated cells. The mRNA expression of fibronectin in the T $\beta 4$ treatment was decreased by $9 \%(p=n s)$ and $34 \%(\mathrm{p}<0.05)$ at $12 \mathrm{~h}$ and $24 \mathrm{~h}$, respectively, compared to the $\mathrm{H}_{2} \mathrm{O}_{2}$-treated cells (Figure 4G).

At translational level, we did not observe any significant change in the CTGF protein level under oxidative stress. However, pretreatment with T $\beta 4$ reduced the expression of CTGF by $27 \%$ $(\mathrm{p}<0.05)$ and $43 \%(\mathrm{p}<0.05)$ at $12 \mathrm{~h}$ and $24 \mathrm{~h}$, respectively, compared to the $\mathrm{H}_{2} \mathrm{O}_{2}$ treated cells. The collagen-I protein expression also increased in $\mathrm{H}_{2} \mathrm{O}_{2}$ treatment by $24 \%(\mathrm{p}<0.05)$ and $21 \%(\mathrm{p}<0.05)$ at $12 \mathrm{~h}$ and $24 \mathrm{~h}$ treatment, respectively, compared to the controls. T $\beta 4$ treatment reduced collagen-I protein 

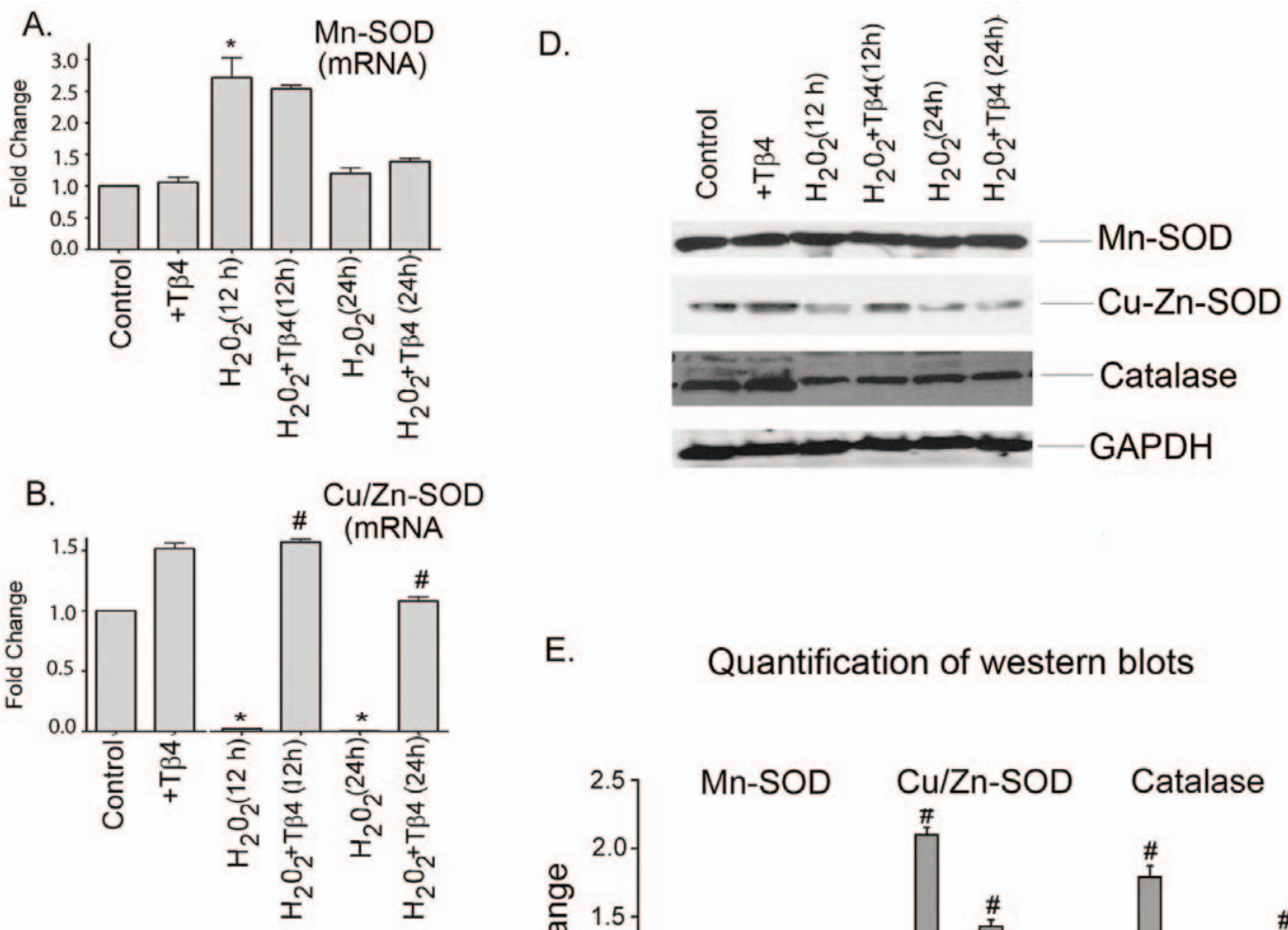

\section{E. Quantification of western blots}
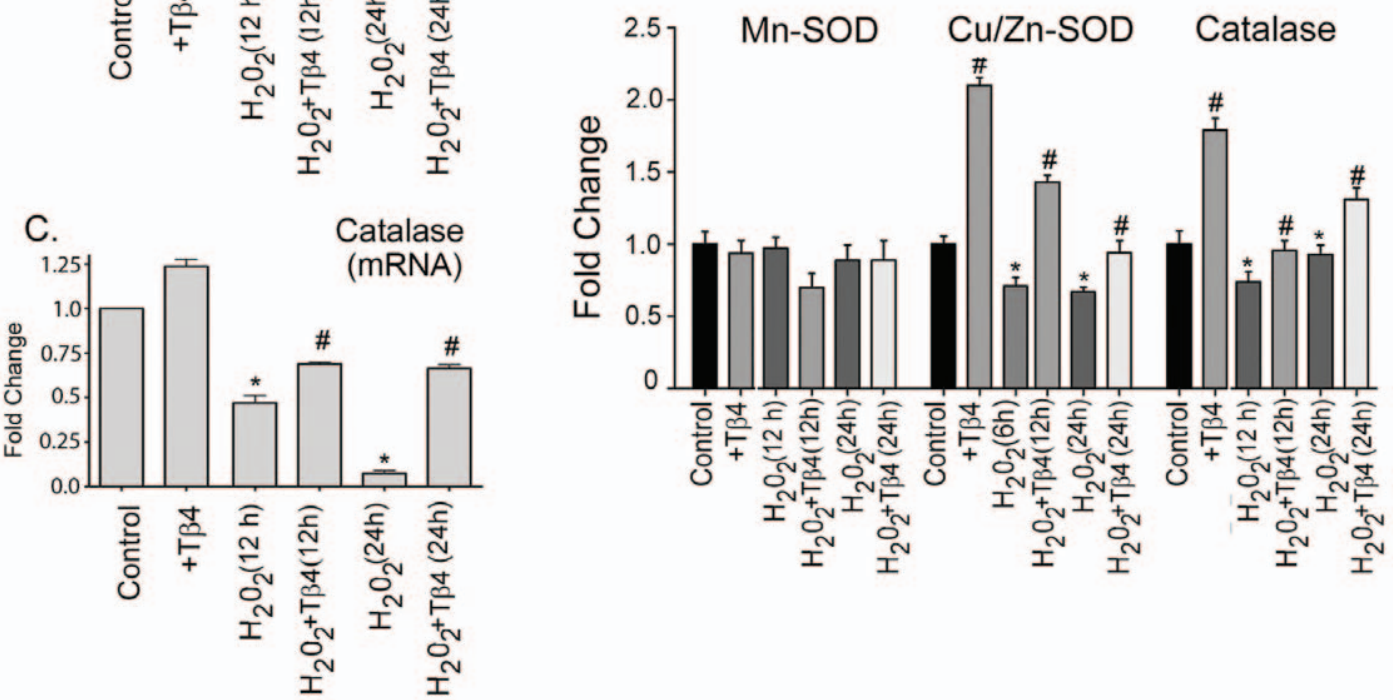

Figure 2. Effect of T/34 on antioxidant genes under oxidative stress in cardiac fibroblasts. Cells were treated with $\mathrm{H}_{2} \mathrm{O}_{2}$ in presence and absence of T $\beta 4$ and (A) Mn-SOD, (B) Cu/Zn-SOD and (C) catalase, mRNA expression were analyzed at $12 \mathrm{~h}$ and $24 \mathrm{~h}$, respectively by qRT-PCR. Data represent the means \pm SE of at least three separate experiments. (D) Western blot analysis showed the protein expression of Mn-SOD, CU/Zn-SOD and catalase at $12 \mathrm{~h}$ and $24 \mathrm{~h}$, respectively. GAPDH was used as internal loading control for the experiment. (E) Graph shows the relative fold change in the protein expression of Mn-SOD, Cu/Zn-SOD and catalase, respectively by densitometry. Data represent means \pm SEM from 3 individual experiments. ${ }^{*}$ denotes $\mathrm{p}<0.05$, compared to controls while ${ }^{\#}$ denotes $\mathrm{p}<0.05$, compared to the $\mathrm{H}_{2} \mathrm{O}_{2}$-treated group.

doi:10.1371/journal.pone.0026912.g002

expression by $17 \%(\mathrm{p}<0.05)$ and $30.5 \%(\mathrm{p}<0.05)$ at $12 \mathrm{~h}$ and $24 \mathrm{~h}$, respectively, compared to the $\mathrm{H}_{2} \mathrm{O}_{2}$ treated cells. The collagen-III protein expression also increased in $\mathrm{H}_{2} \mathrm{O}_{2}$ treatment by $14 \%(\mathrm{p}<0.05)$ and $30 \% \quad(\mathrm{p}<0.05)$ at $12 \mathrm{~h}$ and $24 \mathrm{~h}$, respectively, compared to controls. $\mathrm{T} \beta 4$ treatment reduced the collagen-III expression by $7 \%(\mathrm{p}=\mathrm{ns})$ and $16 \%(\mathrm{p}<0.05)$ at $12 \mathrm{~h}$ and $24 \mathrm{~h}$, respectively, compared to the $\mathrm{H}_{2} \mathrm{O}_{2}$ treated cells (Figure $4 \mathrm{D}$ ). The normalized quantification of each western blot profile is shown (Figure $4 \mathrm{E}$ ).

Effect of knocking down of $\mathrm{Cu} / \mathrm{Zn}-\mathrm{SOD}$, catalase and $\mathrm{BCl}_{2}$ in cardiac fibroblasts

We first determine the efficacy of siRNA mediated transfection of $\mathrm{Cu} / \mathrm{Zn}-\mathrm{SOD}$, catalase and $\mathrm{Bcl}_{2}$ in cardiac fibroblasts. Western blots were performed to confirm the specific knock-down of $\mathrm{Cu}$ / $\mathrm{Zn}-\mathrm{SOD}$, catalase and $\mathrm{Bcl}_{2}$ in cardiac fibroblasts.

To determine whether $\mathrm{T} \beta 4$ has target for $\mathrm{Cu} / \mathrm{Zn}-\mathrm{SOD}$, catalase and $\mathrm{Bcl}_{2}$, we tested the effect of $\mathrm{T} \beta 4$ in the cardiac fibroblasts either transfected with scrambled siRNA or siRNA of catalase, $\mathrm{Cu} / \mathrm{Zn}-\mathrm{SOD}$, and $\mathrm{Bcl}_{2}$ in the presence and absence of $\mathrm{H}_{2} \mathrm{O}_{2}$ induced oxidative stress. Treatment with scrambled siRNA did not alter the expression of catalase, $\mathrm{Cu} / \mathrm{Zn}-\mathrm{SOD}$, and $\mathrm{Bcl}_{2}$; therefore, scrambled siRNA treated group was taken as control for this experiment. Cardiac fibroblasts transfected only with scrambled siRNA showed $15.5 \pm 5.4 \%, \quad 12.6 \pm 6.4 \%$ and $18.1 \pm 0.9 \% \quad(p<0.05)$ increased protein expression of catalase, $\mathrm{Cu} / \mathrm{Zn}-\mathrm{SOD}$ and $\mathrm{Bcl}_{2}$, due to T $\beta 4$ treatment (Fig 5 B, D and E, $2^{\text {nd }}$ lane). $\mathrm{H}_{2} \mathrm{O}_{2}$ treatment under non-silencing (scramble treated) 
A.
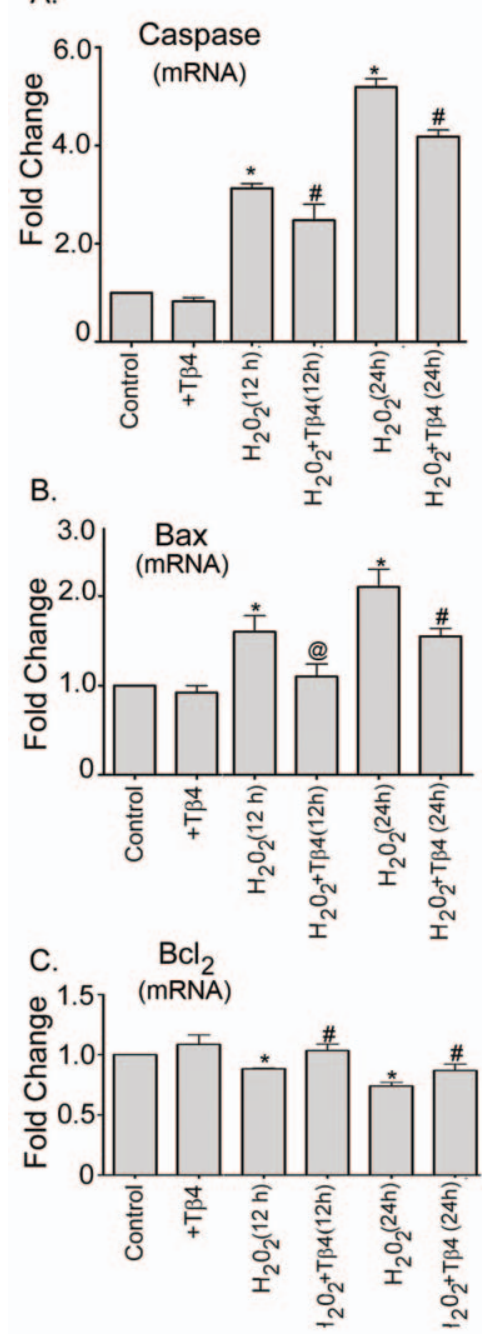
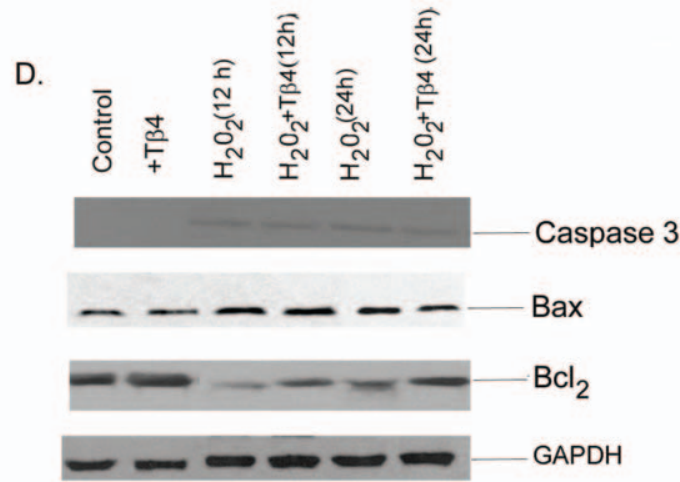

E. Quantification of western blots

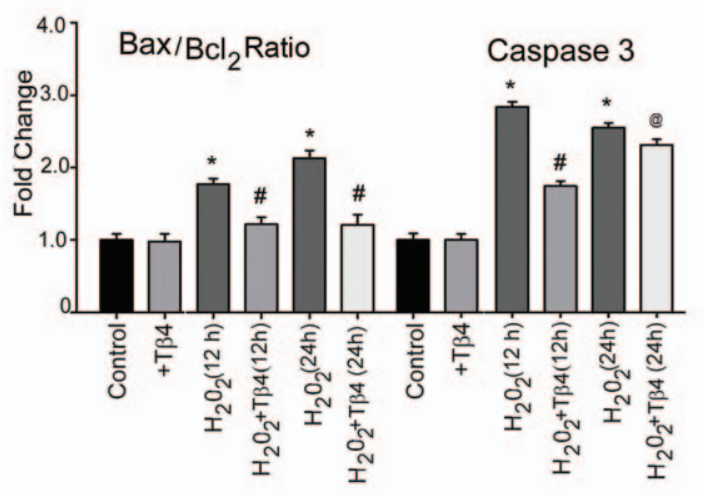

Figure 3. Effect of Tß4 on pro- and anti-apoptotic genes under oxidative stress in cardiac fibroblasts. Cells were treated with $\mathrm{H}_{2} \mathrm{O}_{2}$ in the presence and absence of T $\beta 4$ and (A) Caspase-3, (B) Bax and (C) BCl 2 mRNA expression were analyzed at $12 \mathrm{~h}$ and $24 \mathrm{~h}$, respectively by qRT-PCR. Data represent the means \pm SEM of at least three separate experiments. (D) Protein expression of Caspase-3, Bax and Bcl ${ }_{2}$ at $12 \mathrm{~h}$ and $24 \mathrm{~h}$, respectively. GAPDH was used as loading control for the experiment. (E) GAPDH was used as internal loading control for the experiment. (E) Graph shows the relative fold change in the protein expression of $\mathrm{Bax}, \mathrm{BCl}_{2}$ and caspase-3, respectively by densitometry. Data represent means \pm SEM from 3 individual experiments. ${ }^{*}$ denotes $\mathrm{p}<0.05$ compared to controls while ${ }^{\#}$ denotes $\mathrm{p}<0.05$, compared to the $\mathrm{H}_{2} \mathrm{O}_{2}$-treated group and ${ }^{\circledR}$ means $p=n s$ compared, to the $\mathrm{H}_{2} \mathrm{O}_{2}$-treated group.

doi:10.1371/journal.pone.0026912.g003

conditions resulted in $38.4 \pm 4.2 \%, 63.3 \pm 3.1 \%$ and $56.4 \pm 4.6 \%$ $(\mathrm{p}<0.05)$ down regulation of catalase, $\mathrm{Cu} / \mathrm{Zn}-\mathrm{SOD}$, and $\mathrm{Bcl}_{2}$, respectively, compared to the control (Fig $5 \mathrm{~B}, \mathrm{D}$ and $\mathrm{E}, 3^{\text {rd }}$ lane vs. $1^{\text {st }}$ Lane). In the scramble treated condition, $\mathrm{T} \beta 4$ pre-treatment resulted in significant upregulation of catalase, $\mathrm{Cu} / \mathrm{Zn}-\mathrm{SOD}$, and $\mathrm{Bcl}_{2} \quad(44.6 \pm 3.2 \% ， \quad 145.6 \pm 11.2 \% ， 62.1 \pm 5.7 \%$; respectively, $\mathrm{p}<0.05$ ), compared to $\mathrm{H}_{2} \mathrm{O}_{2}$ treated cardiac fibroblasts (Fig $5 \mathrm{~B}$, $\mathrm{D}$ and $\mathrm{E}, 4^{\text {th }}$ lane).

In comparison to the scrambled siRNA treated set (Fig 5B, D and $\mathrm{F}, 1^{\text {st }}$ lane), our data showed $64.2 \pm 3.1 \%(\mathrm{p}<0.05)$ knockdown of catalase, $77.1 \pm 2.9 \%(\mathrm{p}<0.05)$ knock-down of $\mathrm{Cu} / \mathrm{Zn}$ SOD and $61.2 \pm 3.9 \%(\mathrm{p}<0.05)$ knock-down of $\mathrm{Bcl}_{2}$, when their specific siRNAs were transfected into the fibroblasts (Figure 5A, C and $\mathrm{E}, 1^{\text {st }}$ lane).

The down regulation in the levels of catalase, $\mathrm{Cu} / \mathrm{Zn}-\mathrm{SOD}$ and $\mathrm{Bcl}_{2}$ proteins was abrogated by pre-treatment of T $\beta 4$ (Fig $5 \mathrm{~A}, \mathrm{C}$ and $\mathrm{E}, 2^{\text {nd }}$ lane). We observed that the expression of catalase, $\mathrm{Cu} /$
$\mathrm{Zn}-\mathrm{SOD}$, and $\mathrm{Bcl}_{2}$ was upregulated by $84.5 \pm 5.4 \%, 45.6 \pm 11.2 \%$, $39.8 \pm 6.4 \%$, respectively, $\mathrm{p}<0.05$, compared to their control group (Fig $5 \mathrm{~A}, \mathrm{C}$ and $\mathrm{E}, 1^{\text {st }}$ lane). Furthermore, to evaluate the effect of T $\beta 4$ under more stringent conditions, the siRNA-treated fibroblasts were subjected to $\mathrm{H}_{2} \mathrm{O}_{2}$ challenge, to further enhance the levels of oxidative stress. Our data showed that $\mathrm{H}_{2} \mathrm{O}_{2}$ treatment further depleted the levels of catalase, $\mathrm{Cu} / \mathrm{Zn}-\mathrm{SOD}$ and $\mathrm{Bcl}_{2}$ (Figure $5 \mathrm{~A}, \mathrm{C}, \mathrm{E}\left(3^{\text {rd }}\right.$ Lane). This dual stress ultimately reduced the expression of catalase, $\mathrm{Cu} / \mathrm{Zn}-\mathrm{SOD}$ and $\mathrm{Bcl}_{2}$ to $23.3 \pm 3.8 \%, \quad 17.2 \pm 4.1 \%$ and $12.7 \pm 2.1 \% \quad(\mathrm{p}<0.05)$ of the endogenous levels (Figure 5A, C, E; $3^{\text {rd }}$ Lane). T $\beta 4$ pretreatment resulted in a significant upregulation of catalase and $\mathrm{Cu} / \mathrm{Zn}-\mathrm{SOD}$ $(142.4 \pm 7.3 \%$ and $36.5 \pm 4.1 \%$, respectively, $\mathrm{p}<0.05)$ but not for $\mathrm{Bcl}_{2}(12.5 \pm 8.1 \%, \mathrm{p}>0.05)$, compared to respective controls (Figure 5A, C, E ( $4^{\text {th }}$ Lane). This implicates that under conditions $\mathrm{T} \beta 4$ restored the levels of catalase and $\mathrm{Cu} / \mathrm{Zn}-\mathrm{SOD}$ but failed to restore the expression of $\mathrm{Bcl}_{2}$. GAPDH was used as an internal 
A.
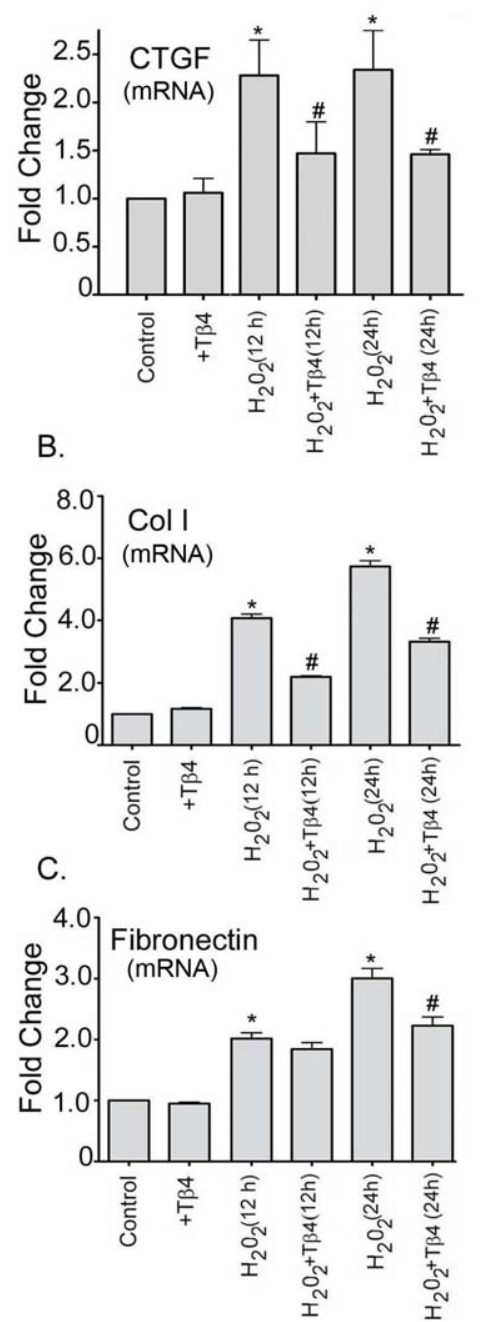

D.

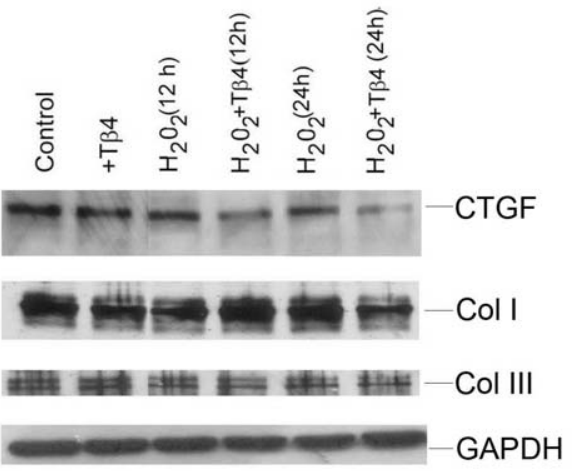

E. Quantification of western blots

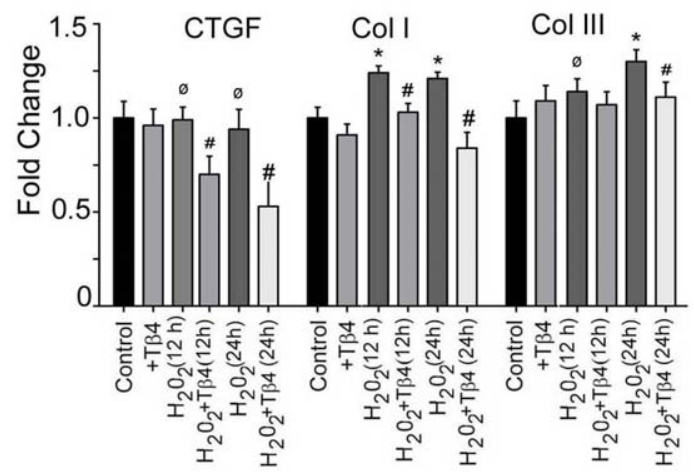

Figure 4. Effect of T $\beta 4$ on profibrotic genes under oxidative stress in cardiac fibroblasts. Cells were treated with $\mathrm{H}_{2} \mathrm{O}_{2}$ in the presence and absence of T $\beta 4$ and (A) CTGF, (B) Col-I and (C) Fibronectin mRNA expression was analyzed at $12 \mathrm{~h}$ and $24 \mathrm{~h}$, respectively by qRT-PCR. Data represent the means \pm SE of three separate experiments. (D) Western blot analysis showed the protein expression of CTGF, Col-I and Col-III at $12 \mathrm{~h}$ and $24 \mathrm{~h}$, respectively. GAPDH was used as a loading control for the experiment. (E) Graph shows the relative fold change in the protein expression of Bax, $\mathrm{BCl}_{2}$ and caspase-3, respectively by densitometry. Data represent means \pm SEM from 3 individual experiments. ${ }^{*}$ denotes $p<0.05$, compared to controls while \# denotes $\mathrm{p}<0.05$ compared to the $\mathrm{H}_{2} \mathrm{O}_{2}$-treated group and $\varnothing$ denotes $\mathrm{p}>0.05$, compared to controls.

doi:10.1371/journal.pone.0026912.g004

loading control (Figure $5 \mathrm{G}$ and $\mathrm{H}$ ). The quantification of knock down of catalase, $\mathrm{Cu} / \mathrm{Zn}-\mathrm{SOD}$ and $\mathrm{Bcl}_{2}$ protein and the restoration of their expression upon $\mathrm{T} \beta 4$ treatment is shown in Fig 5 I.

To test the effect of T $\beta 4$ on induction of apoptosis, we further determined the expression of caspase-3, under the similar condition stated above. In scramble transfected cells, the expression of caspase-3 increased to 3.8-fold $(\mathrm{p}<0.05)$ in $\mathrm{H}_{2} \mathrm{O}_{2}$ treatment, which reduced by $26 \%(\mathrm{p}<0.05)$ upon pretreatment with $\mathrm{T} \beta 4$ (Figure $5 \mathrm{~J}$ ). In $\mathrm{Bcl}_{2}$ knocked down cells, the expression of caspase- 3 increased by 1.7 -fold $(\mathrm{p}<0.05)$, compared to the scrambled siRNA-transfected cells. $\mathrm{H}_{2} \mathrm{O}_{2}$ treatment potentiate a 6.0 -fold $(\mathrm{p}<0.05)$ increase of caspase- 3 , suggesting an additive effect. T $\beta 4$ treatment resulted in an $18 \%$ reduction $(\mathrm{p}<0.05)$ in the expression of caspase-3, compared to $\mathrm{H}_{2} \mathrm{O}_{2}$ stimulated cells (Figure 5J, second group). Similarly, knockdown of catalase gene resulted an increase of 2.1 -fold $(\mathrm{p}<0.05)$ caspase-3 expression. $\mathrm{H}_{2} \mathrm{O}_{2}$ treatment showed an additive effect by increasing a 5.7 -fold $(\mathrm{p}<0.05)$ of caspase-3. T $\beta 4$ pretreatment resulted in a $25 \%$ $(\mathrm{p}<0.05)$ reduction in the caspase-3 activity in the $\mathrm{H}_{2} \mathrm{O}_{2}$ stimulated cells (Figure 5J, third group), compared to the $\mathrm{H}_{2} \mathrm{O}_{2}$ treated group. The expression of caspase- 3 also increased by 1.5fold $(\mathrm{p}<0.05)$ when $\mathrm{Cu} / \mathrm{Zn}-\mathrm{SOD}$ was knocked down in fibroblasts. $\mathrm{H}_{2} \mathrm{O}_{2}$ treatment under similar condition resulted in 4 . 1fold $(\mathrm{p}<0.05)$ increase of caspase- 3 and T $\beta 4$ pretreatment attenuated the caspase- 3 activity by $18 \%(\mathrm{p}<0.05)$, compared to $\mathrm{H}_{2} \mathrm{O}_{2}$ treated cells (Figure 5J, fourth group).

Finally, we performed TUNEL assay under the similar experimental conditions. Our data showed an increase of TUNEL positive nuclei in $\mathrm{H}_{2} \mathrm{O}_{2}$ treated cells as well as knockdown of catalase, $\mathrm{Cu} / \mathrm{Zn}-\mathrm{SOD}$, and $\mathrm{Bcl}_{2}$. Representative of fluorescence microscopy images of TUNEL positive nuclei (FITC-positive) are shown in Figure $6 \mathrm{~A}$ and $\mathrm{B}$. Transfection with scrambled si-RNAs followed by $\mathrm{H}_{2} \mathrm{O}_{2}$ treatment showed an increase of TUNEL positive nuclei from $3.7 \pm 0.3$ to $18.2 \pm 0.4$. Furthermore, knockdown of catalase, $\mathrm{Cu} / \mathrm{Zn}-\mathrm{SOD}$ and $\mathrm{Bcl}_{2}$ resulted in a significant 


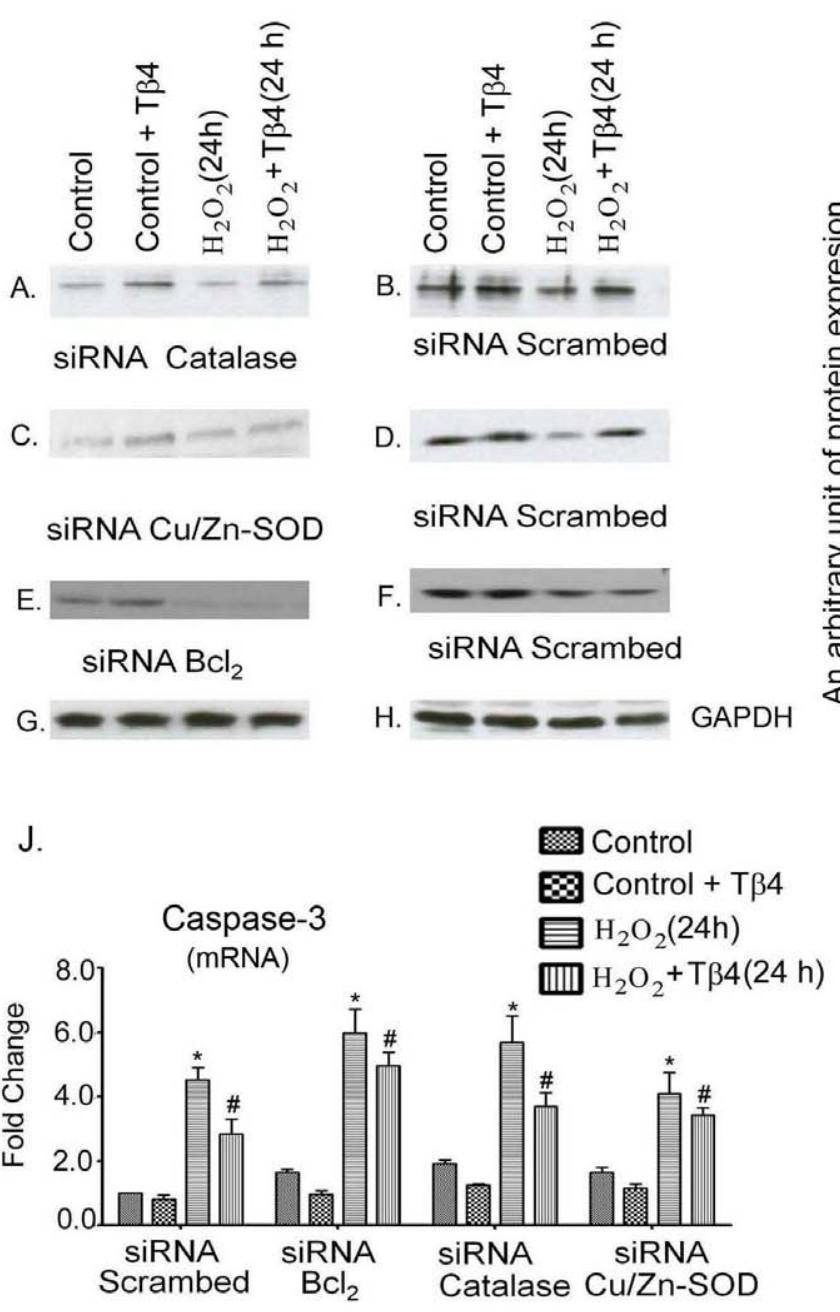

\author{
I.
}

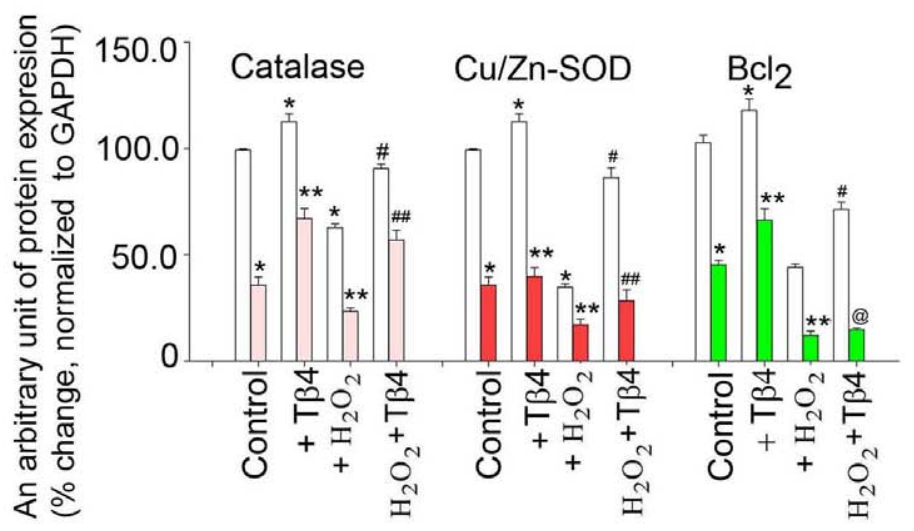

Figure 5. Effect of T/34 on antioxidant and antiapoptotic genes under siRNA knock down of catalase, $\mathrm{Cu} / \mathrm{Zn}$-SOD and Bcl ${ }_{2}$ genes in cardiac fibroblasts under normal and oxidative stress condition. Representative western blot illustrating the restoration of the expression of catalase, $\mathrm{Cu} / \mathrm{Zn}$-SOD and $\mathrm{BCl}_{2}$ in the cardiac fibroblasts upon knockdown of antioxidant and antiapoptotic genes, viz., (A) siRNA-catalase vs. (B) scrambled siRNA; (C) siRNA-Cu/Zn-SOD vs. (D) scrambled siRNA and (E) siRNA-Bcl, vs. (F) scrambled siRNA, respectively. (G and H) GAPDH was used as an internal loading control for the above experiments. (I) Effect of T $\beta 4$ on antioxidant and antiapoptotic genes under control and siRNA knock down of catalase, $\mathrm{Cu} / \mathrm{Zn}$-SOD and $\mathrm{Bcl}_{2}$ genes in cardiac fibroblasts under normal and oxidative stress condition. Data represent the means $\pm \mathrm{SE}$ of at least three separate experiments. Clear bars represent the normalized protein expression of respective proteins in the si-scrambled RNA condition while the color bars represent the normalized protein expression under the respective siRNA knockdown conditions. ${ }^{*}$ denotes $p<0.05$, compared to si-scramble control, ${ }^{*}$ denotes $\mathrm{p}<0.05$, compared to si-scramble and $\mathrm{H}_{2} \mathrm{O}_{2}$ treated group, ${ }^{* *}$ denotes $\mathrm{p}<0.05$, compared to si-RNA control group and \#\# denotes $\mathrm{p}<0.05$, compared to the respective si-RNA and $\mathrm{H}_{2} \mathrm{O}_{2}$ treated group while ${ }^{@}$ denotes $\mathrm{p}=\mathrm{ns}$, compared to si-RNA and $\mathrm{H}_{2} \mathrm{O}_{2}$ treated group. (J) Bar graph shows relative fold-change in the mRNA expression of caspase-3 in T $\beta 4$ pretreated cardiac fibroblasts under respective siRNA knockdown and $\mathrm{H}_{2} \mathrm{O}_{2}$ induced oxidative stress. Data represent the means $\pm S E$ of at least three separate experiments. ${ }^{*}$ denotes $p<0.05$, compared to controls while ${ }^{\#}$ denotes $\mathrm{p}<0.05$ compared to the $\mathrm{H}_{2} \mathrm{O}_{2}$-treated group.

doi:10.1371/journal.pone.0026912.g005

increase in the TUNEL positive nuclei to $26.3 \pm 1.2 \%(\mathrm{p}<0.05)$, $24.0 \pm 3.6 \% \quad(\mathrm{p}<0.05)$ and $30.7 \pm 0.9 \% \quad(\mathrm{p}<0.05)$, respectively (Figure 6 G), compared with the control cells. $\mathrm{H}_{2} \mathrm{O}_{2}$ treatment in the similar experimental set up (knocked down cells), resulted an additive effect and increased the TUNEL positive nuclei to $50.7 \pm 5.9 \%(\mathrm{p}<0.05)$ for catalase, $46.3 \pm 6.6 \%(\mathrm{p}<0.05)$ for $\mathrm{Cu} /$ $\mathrm{Zn}-\mathrm{SOD}$, and $58.7 \pm 10.4 \% \quad(\mathrm{p}<0.05)$ for $\mathrm{Bcl}_{2}$, respectively, compared to the scramble si-RNA $(23.2 \pm 1.9 \%)$. Pretreatment with $\mathrm{T} \beta 4$ in the $\mathrm{H}_{2} \mathrm{O}_{2}$ treated group resulted in a significant reduction in the TUNEL-positive nuclei to $18.0 \pm 2.1 \%(\mathrm{p}<0.05)$ in si-RNAcatalase, $18.7 \pm 2.0 \%(\mathrm{p}<0.05)$ in si-RNA Cu/Zn-SOD, and $31.3 \pm 7.8 \%(\mathrm{p}<0.05)$ in si-RNA $\mathrm{Bcl}_{2}$, respectively (Figure $\left.6 \mathrm{C}\right)$. These results indicate that T $\beta 4$ selectively targets antioxidant and anti-apoptotic genes to provide protection under oxidative stress.

\section{Discussion}

The current study was aimed to determine the target molecules modulated by $\mathrm{T} \beta 4$ that enables it to prevent oxidative stress in an in vitro system using cardiac fibroblasts. $\mathrm{H}_{2} \mathrm{O}_{2}$ induced a marked increase in intracellular ROS in the cardiac fibroblasts. This increase in the intracellular ROS led to altered expression of antioxidant enzymes like the SODs and catalase. Increased ROS also led to the loss of mitochondrial membrane potential and subsequently an increase in the $\mathrm{Bax} / \mathrm{Bcl}_{2}$ ratio favoring apoptosis. This study shows for the first time that T $\beta 4$ reduced the ROS accumulation by modulating the expression of antioxidant enzymes especially catalase and $\mathrm{Cu} / \mathrm{Zn}-\mathrm{SOD}$ and thereby preventing the loss of mitochondrial membrane potential. 
A.

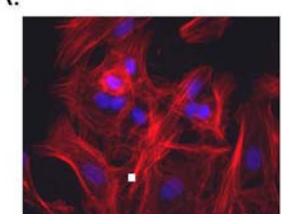

Control
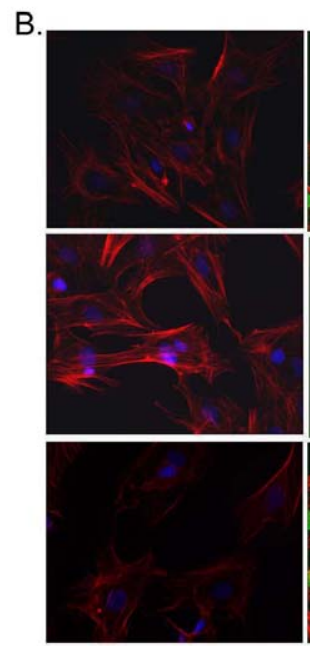

Scrambled

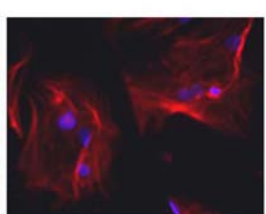

Control+ T $\beta 4$
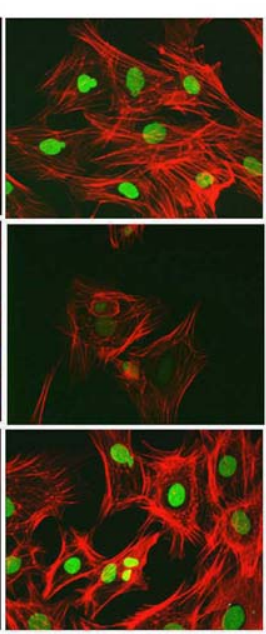

si-RNA $+\mathrm{H}_{2} \mathrm{O}_{2}$

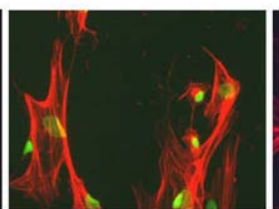

$\mathrm{H}_{2} \mathrm{O}_{2}$
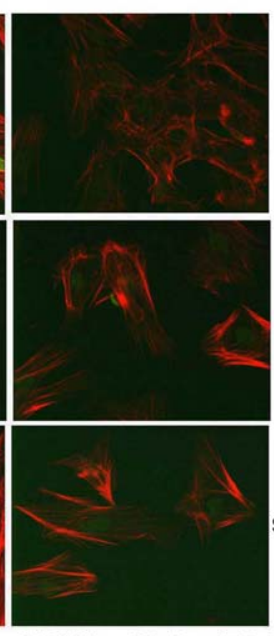

si-RNA + $\mathrm{H}_{2} \mathrm{O}_{2}+\mathrm{T} \beta 4$

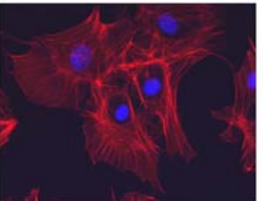

$\mathrm{H}_{2} \mathrm{O}_{2}+\mathrm{T} \beta 4$

Si-RNA + Cu/Zn-SOD

si-RNA-Catalase

si-RNA-Bcl 2

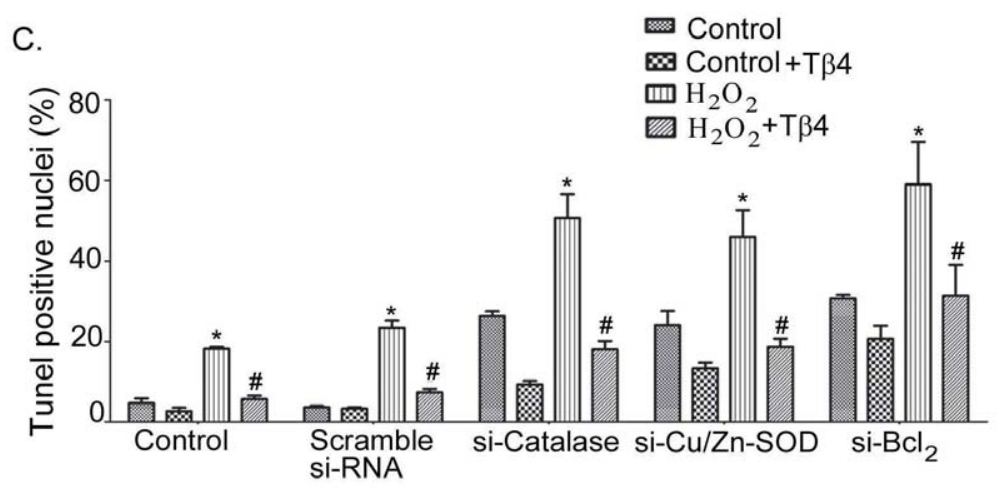

Figure 6. Effect of Tß34 on cardiac fibroblast apoptosis under oxidative stress. (A) Representative fluorescent microscopy images of TUNEL staining in rat neonatal cardiac fibroblasts. Bright TUNEL-positive staining (FITC) was observed in $\mathrm{H}_{2} \mathrm{O}_{2}$ treatment which was not observed in control cells and cells pretreated with T $\beta 4$. DAPI was used to stain the intact nuclei and counterstaining of filamentous actin was done with Texas Red ${ }^{\circledR}-X$ phalloidin. (B) Representative fluorescent microscopy images showing the effect of $\mathrm{T} \beta 4$ treatment in presence and absence $\mathrm{H}_{2} \mathrm{O}_{2}$-induced oxidative stress on cardiac fibroblasts transfected with siRNAs of $\mathrm{Cu} / \mathrm{Zn}-\mathrm{SOD}$, catalase and $\mathrm{BCl}_{2}$ vs. scrambled siRNA, respectively. (C) Bar graph shows the percent TUNEL-positive nuclei under similar experimental condition. Data represent the means \pm SE of at least three separate experiments. A total of 65 to 82 nuclei were counted for each observation. ${ }^{*}$ denotes $\mathrm{p}<0.05$ compared to controls while ${ }^{\#}$ denotes $\mathrm{p}<0.05$, compared to the $\mathrm{H}_{2} \mathrm{O}_{2}$-treated group.

doi:10.1371/journal.pone.0026912.g006

Additionally, T $\beta 4$ upregulated the expression of anti-apoptotic protein $\mathrm{Bcl}_{2}$ and prevented apoptosis of cardiac fibroblasts in response to oxidative stress. T $\beta 4$ failed to alleviate the oxidative stress and prevent cardiac apoptosis when these molecules were knocked down in the cells. Thus, T $\beta 4$ possibly targets antioxidant and anti-apoptotic genes to provide protection under oxidative stress in cardiac fibroblasts.

The myocardium is composed of cardiomyocytes, fibroblasts, endothelial cells and other cell types along with surrounding extracellular matrix (ECM). Apart from the myocytes, cardiac fibroblasts make up the bulk of the myocardium and important cell type as they can play crucial role in cardiac protection by providing sustenance, ECM support and defense against various stress conditions. Therefore, in this study, we used cardiac fibroblasts, so as to study the effect of $\mathrm{T} \beta 4$ on this cell type and to study how oxidative stress affects them in the in vitro system.

In the cardiac cells, $\mathrm{H}_{2} \mathrm{O}_{2}$ is known to induce oxidative stress and apoptosis. This system has been used on various occasions as a model to study the regulation of stress signaling stimuli in cell death $[37,38]$. Here, we used this model system to show the effects of $\mathrm{T} \beta 4$ on $\mathrm{H}_{2} \mathrm{O}_{2}$ induced fibroblast cell death. Our results indicate that $2 \mathrm{~h}$ pretreatment with $\mathrm{T} \beta 4$ is able to significantly decrease the apoptotic effects of $\mathrm{H}_{2} \mathrm{O}_{2}$ in cardiac fibroblasts and thus protecting 
from cell death. These results suggest that intracellular and biochemical effects stimulated by $\mathrm{T} \beta 4$ treatment play a crucial role in the cardio-protection under oxidative stress. $\mathrm{H}_{2} \mathrm{O}_{2}$ treatment on cardiac fibroblasts leads to increase ROS accumulation especially $\mathrm{O}_{2}{ }^{--}, \mathrm{H}_{2} \mathrm{O}_{2}$ or $\mathrm{OH}^{-}$. Superoxide dismutase (SOD) converts $\mathrm{O}_{2}{ }^{-}$ into $\mathrm{H}_{2} \mathrm{O}_{2}$ and the latter can generate hydroxyl $\left(\mathrm{OH}^{-}\right)$radicals in the presence of $\mathrm{Fe}^{2+}$ cations. ROS are able to oxidize biological macromolecules such as DNA, protein and lipids [39,40,41]. Also, NO can also be oxidized into reactive nitric oxide species, which may show behavior similar to that of ROS. In particular, the combination of $\mathrm{NO}$ and $\mathrm{O}_{2}{ }^{--}$can yield a strong biological oxidant, peroxynitrite that is more detrimental to the cells [42]. Oxidative stress causes altered expression of antioxidant enzymes SOD and catalase which prevents effective scavenging of the ROS formed as a result of $\mathrm{H}_{2} \mathrm{O}_{2}$ treatment in the fibroblasts. Our results show that $\mathrm{T} \beta 4$ restored the levels of $\mathrm{Gu} / \mathrm{Zn}-\mathrm{SOD}$ and catalase close to normal physiological level even under oxidative stress and thus scavenging the extra $\mathrm{H}_{2} \mathrm{O}_{2}$-induced ROS from the cellular system. One of the traditional hallmarks of ROS initiated cell death is mitochondrial dysfunction and energy depletion [43]. This is manifested by opening of the mitochondrial permeability transition pore (MPTP), the collapse of the mitochondrial membrane potential $(\Delta \psi \mathrm{m})$ and a concomitant drop in ATP production [44]. These events lead to cascade of cell destruction and apoptosis. Increased production of ROS in the failing heart leads to mitochondrial permeability transition [45], which causes loss of mitochondrial membrane potential, swelling of mitochondrial matrix, release of apoptotic signaling molecules, such as cytochrome c, from the inter-membrane space, and irreversible injury to the mitochondria [46]. Increased ROS in our system led to a decrease in the $\Delta \psi \mathrm{m}$ as evident by the staining with MitoTracker Red. This loss of $\Delta \psi \mathrm{m}$ was prevented by pretreatment of $\mathrm{T} \beta 4$. At this point, it is beyond our scope to investigate how T $\beta 4$ modulate mitochondrial membrane potential under oxidative stress and, therefore, warranted further investigation.

T $\beta 4$ was extremely effective in reducing intracellular ROS in $\mathrm{H}_{2} \mathrm{O}_{2}$ treated cardiac fibroblasts (Figure $2 \mathrm{~A}-\mathrm{C}$ ). T $\beta 4$ acts via upregulation of selected antioxidant genes like $\mathrm{Cu} / \mathrm{Zn}-\mathrm{SOD}$ and catalase. In fact, the intracellular ROS level was markedly reduced when the cells were pretreated with $\mathrm{T} \beta 4$ at least $2 \mathrm{~h}$ prior to $\mathrm{H}_{2} \mathrm{O}_{2}$ exposure, suggesting that it might activate the key molecules that play an important role in the enzymatic antioxidant defense system. Another particularly relevant protein that loses function upon oxidation is Mn-SOD; its loss of function would further compromise antioxidant capacity and lead to further oxidative stress [47]. Both Mn-SOD and $\mathrm{Cu} / \mathrm{Zn}-\mathrm{SOD}$ have been reported to play a crucial role in protecting the cardiac cells from oxidative damage by scavenging ROS [48]. In our experimental system, we found that T $\beta 4$ upregulated the expression levels of $\mathrm{Cu} / \mathrm{Zn}-\mathrm{SOD}$ and not Mn-SOD in cardiac fibroblast thus affording cardiac protection which is in contrast to the previous report by Ho et al [23]. This could be probably due to the different cell type used in the study. Catalase, which was directly responsible for $\mathrm{H}_{2} \mathrm{O}_{2}$ clearance, was upregulated by $\mathrm{T} \beta 4$ both at protein and gene level in the presence of $\mathrm{H}_{2} \mathrm{O}_{2}$, indicating that $\mathrm{T} \beta 4$ preferentially targets catalase which enables effecting scavenging of the $\mathrm{H}_{2} \mathrm{O}_{2}$ from the system. The mechanism of $\mathrm{Cu} / \mathrm{Zn}-\mathrm{SOD}$ and catalase upregulation by $\mathrm{T} \beta 4$ is currently unknown but, a transcription factor mediator activity has been postulated [49]. T $\beta 4$ has been reported to translocate into the nucleus by an active transport mechanism or possibly through its cluster of positively charged amino acid residues (KSKLKK) but the exact function is still obscure. Alternatively, it might be the similar event like nuclear localization of actin where it is postulated that it might involve in chromatin remodeling [50], mRNA processing and transport [51].

Improved fibroblast survival during oxidative stress is important because increased fibroblast survival belittles the cardiac injury and prevents overall damage to the heart. Oxidative stress is known to trigger apoptotic cell death by up regulating the expression of pro-apoptotic protein like Bax which then dimerises and translocate to the outer mitochondrial membrane and aggregates to form pores that permit cytochrome $c$ from mitochondria to cytosol [52]. Oxidative stress also leads to activation of caspase-3 cleavage and initiation of intrinsic apoptotic pathway [52]. Therefore, reduction in the production and accumulation of intracellular ROS is important to protect the cells from apoptosis triggered by the intrinsic pathway. Our data further showed that $\mathrm{T} \beta 4$ treatment inhibits excessive Bax expression and caspase- 3 activation and enhance $\mathrm{Bcl}_{2}$ expression in fibroblast suggesting its protective effects under oxidative stress. As $T \beta 4$ reduces the intracellular ROS levels, it would be reasonable to explain that $\mathrm{T} \beta 4$ probably promote the $\mathrm{Bcl}_{2} / \mathrm{Bax}$ ratio to protect the cells from apoptosis. To best of our knowledge, this is the first report that elucidates the beneficial effect of T $\beta 4$ in cardiac fibroblast by up regulating the $\mathrm{Bcl}_{2} / \mathrm{Bax}$ ratio in favor of cell survival. This finding is in contrast to the previous report by Sosne et al, where they did not observe any change in the Bax/ $\mathrm{Bcl}_{2}$ expression [18]. This could be probably due to the different cell type used in the study. Although, there is no definitive mechanism by which T $\beta 4$ exerts this anti-apoptotic effects, but, an internalization of $\mathrm{T} \beta 4$ has been proposed as one of the possible mechanism in human corneal epithelial cell under oxidative stress [19]. Alternatively, T $\beta 4$ may use its methionine residues to react with intracellular oxygen at the post-translational level to generate sulfoxide, reducing the ROS level and eventually protects the cells from apoptosis [53].

Increased oxidative stress leads to pro-fibrotic changes in the fibroblasts $[54,55]$. We observed that there was an increase in the expression of pro-fibrotic genes like CTGF, Collagen-I, CollgenIII and fibronectin in cardiac fibroblasts treated with $\mathrm{H}_{2} \mathrm{O}_{2}$. Decreased expression of fibrotic genes in the fibroblasts is beneficial because it prevents cardiac fibrosis and stiffening by reducing the ECM deposition. Our study showed that the increase in the pro-fibrotic gene expression was prevented by pretreatment of fibroblasts with $\mathrm{T} \beta 4$. These results corroborated with our previous observation in myocardial infarction (MI) model [22]. We showed that $\mathrm{T} \beta 4$ abrogated cardiac fibrosis in post-MI period by attenuating collagen type I and type III gene expression. This is the first report that elucidates the down regulation of pro-fibrotic gene expression by $\mathrm{T} \beta 4$ under oxidative stress.

Interestingly, we found that $\mathrm{T} \beta 4$ prevented apoptotic cell death by specifically targeting these antioxidant and anti-apoptotic molecules and when these antioxidant and apoptotic molecules were knocked down by si-RNA treatment; T $\beta 4$ was not able to contribute its cardio-protective effects. These findings led us to suggest that $\mathrm{T} \beta 4$ provide cardiac protection by reducing the intracellular ROS levels and enhancing the expression of antioxidant enzymes (Cu/Zn-SOD and catalase) and antiapoptotic protein $\left(\mathrm{Bcl}_{2}\right)$ under oxidative stress.

In conclusion, we demonstrated that $\mathrm{T} \beta 4$ protects the cardiac fibroblasts against apoptosis by reducing intracellular oxidative stress through enhancing the expression of selected anti-oxidative enzymes and anti-apoptotic proteins. Given the preference of cardio-protective effects of $\mathrm{T} \beta 4$, it is still not clear how $\mathrm{T} \beta 4$ exerts its beneficial effects, is still under investigation. Although, T $\beta 4$ is internalized by cells but the cell surface receptors are still not known. Furthermore, high concentration and ubiquitous presence 
of T $\beta 4$ in the organs/tissues, it is reasonable to advocate that T $\beta 4$ functions as an important intracellular mediator when either release from the cells or exogenously added, acts as a moonlighting peptide for repairing the damages tissues or cells [56,57]. Our results not only offered more mechanistic explanation about the protective mechanism of $\mathrm{T} \beta 4$ but also supported the need to further investigate the use of this peptide in protecting the myocardium against oxidative damage in variety of disease condition where ROS has been implicated to play a damaging role. Also, further investigations are needed to explore the antifibrotic properties of $\mathrm{T} \beta 4$ which could be used to alleviate detrimental conditions like cardiac fibrosis, hypertrophy and heart failure.

\section{Clinical Implications}

Many studies have shown that there is a depletion of antioxidant levels due to aging especially in the heart, which makes it more vulnerable to damage especially under ischemia and under high pro-oxidant condition. We believe that the identified molecules $\left(\mathrm{Cu} / \mathrm{Zn}-\mathrm{SOD}\right.$, catalase and $\left.\mathrm{Bcl}_{2}\right)$ are important players

\section{References}

1. Dimmeler S, Zeiher AM (2007) A "reductionist" view of cardiomyopathy. Cell 130: 401-402.

2. Matata BM, Elahi MM (2007) Oxidative stress: clinical and biomedical implications. New York: Nova Biomedical Books. vi. 330 p.

3. Sadoshima J (2006) Redox regulation of growth and death in cardiac myocytes. Antioxid Redox Signal 8: 1621-1624.

4. Kukin ML, Fuster V (2003) Oxidative stress and cardiac failure. Armonk, NY: Futura Pub. xx, 291.

5. Cohen J, Shah PM (1974) Cardiac hypertrophy and cardiomyopathy. Jules Cohen, Pravin M. Shah, eds. Proceedings of a symposium held October 1972 in Rochester, New York. New York: American Heart Assn. 223 p.

6. Dhalla AK, Singal PK (1994) Antioxidant changes in hypertrophied and failing guinea pig hearts. Am J Physiol 266: H1280-1285.

7. Maron BJ, Salberg L (2006) Hypertrophic cardiomyopathy : for patients, their families, and interested physicians. Malden, Mass.: Blackwell Pub. xi. 113 p.

8. Poornima IG, Parikh P, Shannon RP (2006) Diabetic Cardiomyopathy: The Search for a Unifying Hypothesis. Circ Res 98: 596-605.

9. Chen Y, Saari JT, Kang YJ (1994) Weak antioxidant defenses make the heart a target for damage in copper-deficient rats. Free Radical Biology and Medicine 17: $529-536$.

10. Ide T, Tsutsui H, Kinugawa S, Utsumi H, Kang D, et al. (1999) Mitochondrial electron transport complex I is a potential source of oxygen free radicals in the failing myocardium. Circ Res 85: 357-363.

11. George J, Struthers AD (2009) Role of urate, xanthine oxidase and the effects of allopurinol in vascular oxidative stress. Vasc Health Risk Manag 5: 265-272.

12. Bubb MR (2003) Thymosin beta 4 interactions. Vitamins and hormones 66: 297-316.

13. Malinda KM, Goldstein AL, Kleinman HK (1997) Thymosin beta 4 stimulates directional migration of human umbilical vein endothelial cells. The FASEB journal: official publication of the Federation of American Societies for Experimental Biology 11: 474-481.

14. Bock-Marquette I, Saxena A, White MD, Dimaio JM, Srivastava D (2004) Thymosin beta4 activates integrin-linked kinase and promotes cardiac cell migration, survival and cardiac repair. Nature 432: 466-472.

15. Smart N, Risebro CA, Clark JE, Ehler E, Miquerol L, et al. (2010) Thymosin beta4 facilitates epicardial neovascularization of the injured adult heart. Annals of the New York Academy of Sciences 1194: 97-104.

16. Qiu F-Y, Song X-X, Zheng H, Zhao Y-B, Fu G-S (2009) Thymosin [beta] 4 Induces Endothelial Progenitor Cell Migration via PI3K/Akt/eNOS Signal Transduction Pathway. Journal of Cardiovascular Pharmacology 53: 209-214 210 .

17. Goldstein AL, Garaci E (2010) Thymosins in health and disease: 2nd international symposium. Boston, Mass: Blackwell Pub. on behalf of the New York Academy of Sciences. xi. 230 p.

18. Sosne G, Siddiqi A, Kurpakus-Wheater M (2004) Thymosin-\{beta 4 Inhibits Corneal Epithelial Cell Apoptosis after Ethanol Exposure In Vitro. Invest Ophthalmol Vis Sci 45: 1095-1100.

19. Ho JH-C, Chuang C-H, Ho G-Y, Shih Y-RV, Lee OK-S, et al. (2007) Internalization Is Essential for the Antiapoptotic Effects of Exogenous Thymosin \{beta\}-4 on Human Corneal Epithelial Cells. Invest Ophthalmol Vis Sci 48: 27-33.

20. Sosne G, Albeiruti A-R, Hollis B, Siddiqi A, Ellenberg D, et al. (2006) Thymosin [beta] 4 inhibits benzalkonium chloride-mediated apoptosis in corneal and conjunctival epithelial cells in vitro. Experimental Eye Research 83: 502-507. under oxidative stress to mitigate the damage. Our findings indicated that the beneficial role of $\mathrm{T} \beta 4$ and its effects on upregulation of anti-oxidant genes under oxidative stress in the cardiac fibroblasts might be of clinical relevance. This makes T $\beta 4$ a better therapeutic target and could have wider implications once translated from bench to bedside.

\section{Limitation of the Study}

In this study, we validated the effect of $\mathrm{T} \beta 4$ by selectively knocking down the anti-oxidant and apoptotic genes targeted by $\mathrm{T} \beta 4$ in cardiac fibroblasts. However, the possibility of interaction between these genes and other molecular pathways cannot be ignored. Also other off target effects of our anti-oxidative strategies with $\mathrm{T} \beta 4$ in conditions like cardiac fibrosis, cardiomyopathies and heart failure needs to be further investigated.

\section{Author Contributions}

Conceived and designed the experiments: SG. Performed the experiments: SK. Analyzed the data: SG SK. Wrote the paper: SG SK.

21. Shrivastava S, Srivastava D, Olson EN, DiMaio JM, Bock-Marquette I (2010) Thymosin beta4 and cardiac repair. Ann N Y Acad Sci 1194: 87-96.

22. Sopko N, Qin Y, Finan A, Dadabayev A, Chigurupati S, et al. (2011) Significance of Thymosin beta4 and Implication of PINCH-1-ILK-alpha-Parvin (PIP) Complex in Human Dilated Cardiomyopathy. PloS one 6: e20184.

23. Ho JH, Tseng KC, Ma WH, Chen KH, Lee OK, et al. (2008) Thymosin beta-4 upregulates anti-oxidative enzymes and protects human cornea epithelial cells against oxidative damage. Br J Ophthalmol 92: 992-997.

24. Ieda M, Tsuchihashi T, Ivey KN, Ross RS, Hong T-T, et al. (2009) Cardiac Fibroblasts Regulate Myocardial Proliferation through ${ }^{2} 1$ Integrin Signaling. Developmental cell 16: 233-244.

25. Leask A (2007) TGF 3 , cardiac fibroblasts, and the fibrotic response. Cardiovascular research 74: 207-212.

26. Squires CE, Escobar GP, Payne JF, Leonardi RA, Goshorn DK, et al. (2005) Altered fibroblast function following myocardial infarction. Journal of molecular and cellular cardiology 39: 699-707.

27. Jelaska A, Strehlow D, Korn JH (1999) Fibroblast heterogeneity in physiological conditions and fibrotic disease. Springer Semin Immunopathol 21: 385-395.

28. Brown RD, Ambler SK, Mitchell MD, Long CS (2005) The cardiac fibroblast: therapeutic target in myocardial remodeling and failure. Annu Rev Pharmacol Toxicol 45: 657-687.

29. Takeda N, Manabe I, Uchino Y, Eguchi K, Matsumoto S, et al. (2010) Cardiac fibroblasts are essential for the adaptive response of the murine heart to pressure overload. The Journal of clinical investigation 120: 254-265.

30. Kawaguchi M, Takahashi M, Hata T, Kashima Y, Usui F, et al. (2011) Inflammasome Activation of Cardiac Fibroblasts Is Essential for Myocardial Ischemia/Reperfusion Injury. Circulation 123(6): 594-604.

31. Gupta S, Purcell NH, Lin A, Sen S (2002) Activation of nuclear factor- $\kappa$ B is necessary for myotrophin-induced cardiac hypertrophy. The Journal of Cell Biology 159: 1019-1028.

32. Schorb W, Booz G, Dostal D, Conrad K, Chang K, et al. (1993) Angiotensin II is mitogenic in neonatal rat cardiac fibroblasts. Circ Res 72: 1245-1254.

33. Kumar S, Kain V, Sitasawad SL (2009) Cardiotoxicity of calmidazolium chloride is attributed to calcium aggravation, oxidative and nitrosative stress, and apoptosis. Free Radic Biol Med 47: 699-709.

34. Elia L, Contu R, Quintavalle M, Varrone F, Chimenti C, et al. (2009) Reciprocal regulation of microRNA-1 and insulin-like growth factor-1 signal transduction cascade in cardiac and skeletal muscle in physiological and pathological conditions. Circulation 120: 2377-2385.

35. Livak KJ, Schmittgen TD (2001) Analysis of Relative Gene Expression Data Using Real-Time Quantitative PCR and the 2-[Delta][Delta]CT Method. Methods 25: 402-408.

36. Pfaffl MW (2001) A new mathematical model for relative quantification in realtime RT-PCR. Nucleic Acids Research 29: e45.

37. Murata H, Ihara Y, Nakamura H, Yodoi J, Sumikawa K, et al. (2003) Glutaredoxin exerts an antiapoptotic effect by regulating the redox state of Akt. J Biol Chem 278: 50226-50233.

38. Han H, Long H, Wang H, Wang J, Zhang Y, et al. (2004) Progressive apoptotic cell death triggered by transient oxidative insult in $\mathrm{H} 9 \mathrm{c} 2$ rat ventricular cells: a novel pattern of apoptosis and the mechanisms. Am J Physiol Heart Circ Physiol 286: H2169-2182

39. Frank H, Thiel D, MacLeod J (1989) Mass spectrometric detection of crosslinked fatty acids formed during radical-induced lesion of lipid membranes. Biochem J 260: 873-878. 
40. Dean RT, Fu S, Stocker R, Davies MJ (1997) Biochemistry and pathology of radical-mediated protein oxidation. Biochem $\mathrm{J} 324$ ( Pt 1): 1-18.

41. Breen AP, Murphy JA (1995) Reactions of oxyl radicals with DNA. Free Radic Biol Med 18: 1033-1077.

42. Murphy MP, Packer MA, Scarlett JL, Martin SW (1998) Peroxynitrite: a biologically significant oxidant. Gen Pharmacol 31: 179-186.

43. Crawford DR, Davies KJ (1994) Adaptive response and oxidative stress. Environ Health Perspect 102 Suppl 10: 25-28.

44. Pereira CV, Moreira AC, Pereira SP, Machado NG, Carvalho FS, et al. (2009) Investigating drug-induced mitochondrial toxicity: a biosensor to increase drug safety? Curr Drug Saf 4: 34-54.

45. Weiss JN, Korge P, Honda HM, Ping P (2003) Role of the mitochondrial permeability transition in myocardial disease. Circ Res 93: 292-301.

46. Baines CP, Kaiser RA, Purcell NH, Blair NS, Osinska H, et al. (2005) Loss of cyclophilin $\mathrm{D}$ reveals a critical role for mitochondrial permeability transition in cell death. Nature 434: 658-662.

47. MacMillan-Crow LA, Crow JP, Thompson JA (1998) Peroxynitrite-mediated inactivation of manganese superoxide dismutase involves nitration and oxidation of critical tyrosine residues. Biochemistry 37: 1613-1622.

48. Rahman K (2007) Studies on free radicals, antioxidants, and co-factors. Clin Interv Aging 2: 219-236.

49. Huff T, Rosorius O, Otto AM, Muller CS, Ballweber E, et al. (2004) Nuclear localisation of the $\mathrm{G}$-actin sequestering peptide thymosin beta4. Journal of cell science 117: 5333-5341.
50. Shen X, Ranallo R, Choi E, Wu C (2003) Involvement of actin-related proteins in ATP-dependent chromatin remodeling. Molecular cell 12: 147-155.

51. Percipalle P, Zhao J, Pope B, Weeds A, Lindberg U, et al. (2001) Actin bound to the heterogeneous nuclear ribonucleoprotein hrp36 is associated with Balbiani ring mRNA from the gene to polysomes. The Journal of Cell Biology 153: 229-236.

52. Hori M, Nishida K (2009) Oxidative stress and left ventricular remodelling after myocardial infarction. Cardiovasc Res 81: 457-464.

53. Young JD, Lawrence AJ, MacLean AG, Leung BP, McInnes IB, et al. (1999) Thymosin beta 4 sulfoxide is an anti-inflammatory agent generated by monocytes in the presence of glucocorticoids. Nature medicine 5: 1424-1427.

54. Iglesias-De La Cruz MC, Ruiz-Torres P, Alcami J, Diez-Marques L, OrtegaVelazquez R, et al. (2001) Hydrogen peroxide increases extracellular matrix mRNA through TGF-beta in human mesangial cells. Kidney Int 59: 87-95.

55. Suh JH, Shigeno ET, Morrow JD, Cox B, Rorcha AE, et al. (2001) Oxidative stress in the aging rat heart is reversed by dietary supplementation with $(R)$ \{alpha\}-lipoic acid. FASEB J 15: 700-706.

56. Goldstein AL, Hannappel E, Kleinman HK (2005) Thymosin beta4: actinsequestering protein moonlights to repair injured tissues. Trends in molecular medicine 11: 421-429.

57. Crockford D, Turjman N, Allan C, Angel J (2010) Thymosin beta4: structure, function, and biological properties supporting current and future clinical applications. Annals of the New York Academy of Sciences 1194: 179-189. 